UNIVERSIDADE DE SÃO PAULO

ESCOLA DE COMUNICAÇÕES E ARTES

DENISE PATARRA

\title{
O VÔO DE BARTOLOMEU \\ NO ROTEIRO CINEMATOGRÁFICO \\ O PADRE VOADOR
}

Tese apresentada à Escola de Comunicações e Artes da Universidade de São Paulo, como exigência parcial para obtenção do Título de Doutora em Ciências da Comunicação, sob a orientação do Professor Doutor Ismail Xavier. 
UNIVERSIDADE DE SÃO PAULO

ESCOLA DE COMUNICAÇÕES E ARTES

DENISE PATARRA

\section{O VÔO DE BARTOLOMEU \\ NO ROTEIRO CINEMATOGRÁFICO \\ O PADRE VOADOR}

Tese apresentada à Escola de Comunicações e Artes da Universidade de São Paulo, como exigência parcial para obtenção do Título de Doutora em Ciências da Comunicação, sob a orientação do Professor Doutor Ismail Xavier. 
Patarra, Denise

O Vôo de Bartolomeu no roteiro cinematográfico

O Padre Voador / Denise Patarra. - São Paulo: D. Patarra, 2008.

$\mathrm{N}$ p.

Tese (Doutorado) - Departamento de Cinema, Televisão e Rádio/ Escola de Comunicações e Artes/USP, 27/06/2008.

Orientador: Professor Doutor Ismail Xavier.

Filmografia/Bibliografia

1. Memória do Projeto

2. Roteiro Cinematográfico 

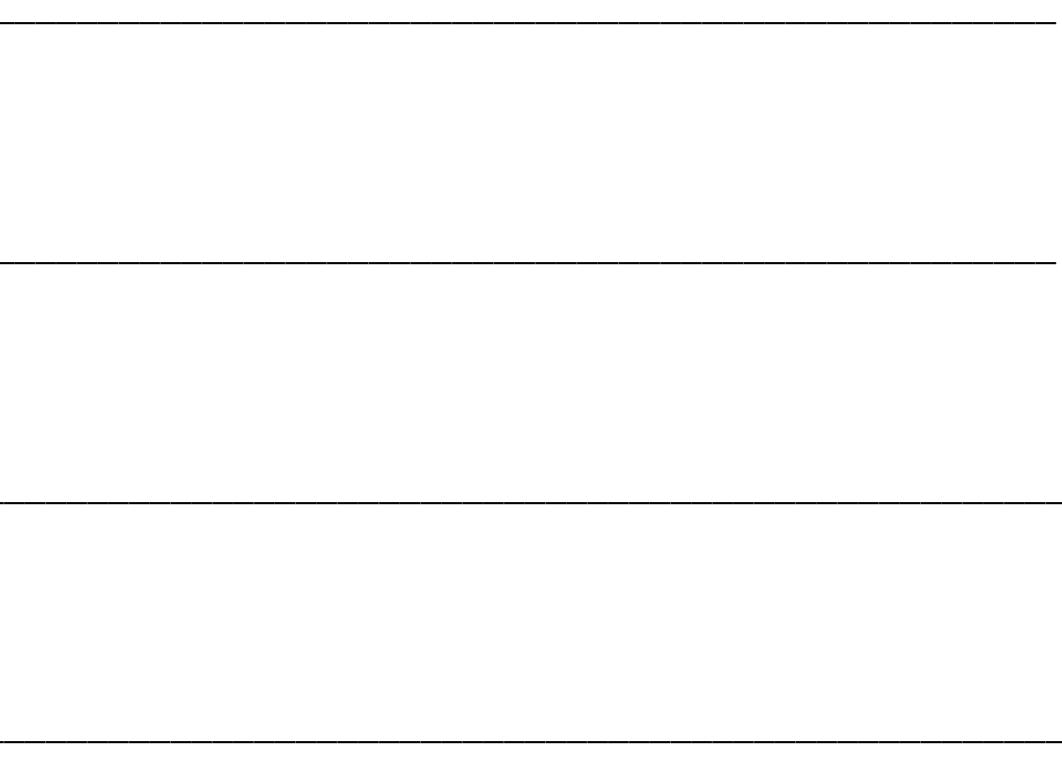


\section{Agradecimentos}

Ao professor doutor Ismail Xavier, por me ter ensinado a pensar nos filmes com maior profundidade e por me acolher no meio do caminho.

Às professoras doutoras Anita Novinsky e Maria Luiza Tucci Carneiro pelas luzes históricas. Aos professores doutores Flávio Aguiar e Roberto Moreira pela leitura atenta do primeiro tratamento e suas valiosas contribuições no Exame de Qualificação.

A Lucas Cifani Pacheco por bancar a tentativa de realização do filme, à Mariana Ferreira pelo Abstract e à minha mãe, Judith Lieblich Patarra, pelas leituras e opiniões. 


\section{Resumo}

Esta tese trata da criação do roteiro cinematográfico O Padre Voador. Acompanha o roteiro a memória de sua escrita, dividida em começo e meio. O começo narra o princípio da idéia e o envolvimento com a história de Bartolomeu Lourenço de Gusmão, em minha graduação na Letras; o início da pesquisa sobre o personagem e a escritura do argumento já no mestrado da mesma FFLCH-USP. No meio houve a possibilidade de sonhar com a realização do filme, daí a entrada no doutorado desta Escola de Comunicações e Artes sob a orientação do professor doutor Ismail Xavier, e o desenvolvimento da pesquisa sobre a época de Bartolomeu de Gusmão no Departamento de História. Do meio consta ainda o primeiro tratamento, submetido à atenciosa leitura dos professores doutores Flávio Aguiar e Roberto Moreira, no Exame de Qualificação. O fim é o segundo tratamento do roteiro, onde procurei absorver os valiosos pareceres dos professores e as fundamentais opiniões do orientador.

Palavras Chaves: Cinema, Roteiro, Inquisição, Bartolomeu, Balão. 


\begin{abstract}
This term paper is about the creation of the screenplay O Padre Voador. Along with the screenplay we present the process of writing the script, divided into beginning and middle sections. The beginning narrates the idea and the involvement with the story of Bartolomeu Lourenço de Gusmão, which I developed as a graduate student in Languages Arts. I completed the first steps of character development and the writing of the plot for my Master's Degree at FFLCH-USP. The middle section addresses the realization that my dream of producing the film could be true. Therefore I enrolled in the doctorate program at this Escola de Comunicações e Artes under the guidance of Professor Ismail Xavier. The historical study of the century in which Bartolomeu lived was made possible with the aid of the History Department. In the middle section we also find the first version of the screenplay, submitted to Professors Flavio Aguiar and Roberto Moreira during the qualifying exam. The end consists of the second version of the screenplay, where I tried to incorporate the professors' valuable suggestions and the fundamental view of the advisor.
\end{abstract}

Key terms: Cinema, Screenplay, Inquisition, Bartolomeu, Baloon. 


\section{Sumário}

Capítulo 1

Apresentação do Engenho:

Memória do Projeto

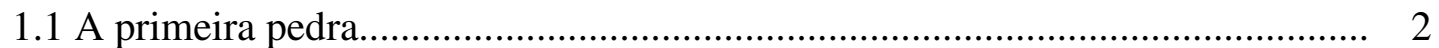

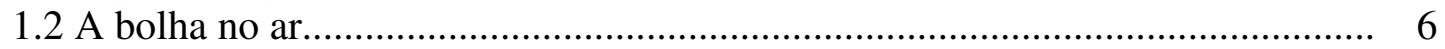

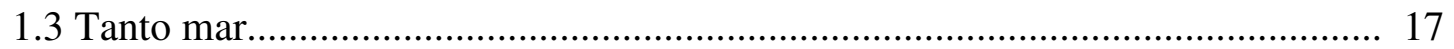

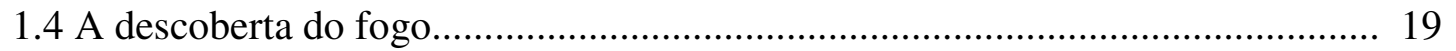

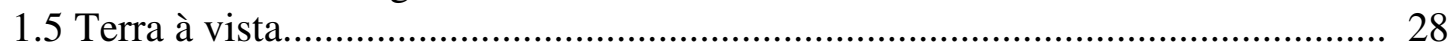

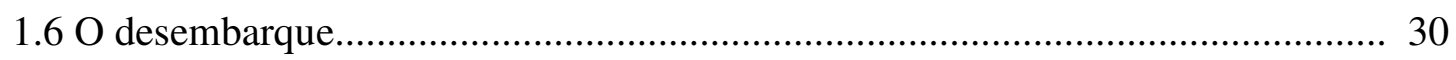

Capítulo 2

A Escavação:

Roteiro Cinematográfico

2.1 O Padre Voador. 34

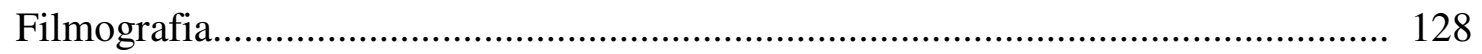

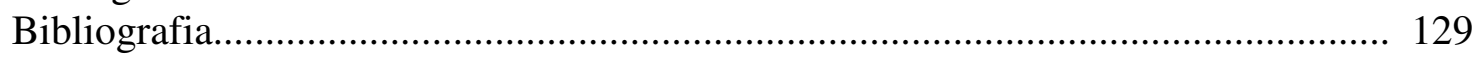


Capítulo 1

Apresentação do Engenho

Memória do Projeto 


\section{A primeira pedra}

\section{Inteiro é o que tem começo, meio e fim. ${ }^{1}$}

O começo desta tese-roteiro, da área de Estudos dos Meios e da Produção Mediática, foi minha dissertação de Mestrado em Letras. Lá se encontram os preâmbulos da fábula e da história de Bartolomeu Lourenço de Gusmão. Aqui vem o segundo tratamento do roteiro cinematográfico de longa-metragem $O$ Padre Voador. Trata-se dos primórdios do Brasil, da nossa origem, um "filme histórico" de ficção. O percurso vivido por Bartolomeu de Gusmão no começo do século dezoito veio se transformando a partir dos pontos de vista daqueles que contaram a sua vida e, no roteiro, provavelmente também.

Apesar do conhecido pouco caso do brasileiro com o seu passado, sempre houve filmes que procuraram investigar a nossa história. $\mathrm{O}$ primeiro foi talvez o mais importante: Descobrimento do Brasil, de Humberto Mauro. Segundo Paulo Emílio Salles Gomes, a fita "tem um frescor de tratamento histórico que é raro em qualquer cinematografia." 2

São parte dessa tradição filmes de estilos e épocas diversas como Os inconfidentes, de Joaquim Pedro de Andrade; História do Brazyl, de Glauber Rocha e Marcos Medeiros; Xica da Silva, de Cacá Diegues; Carlota Joaquina, de Carla Camurati; Hans Staden, de Luís Alberto Pereira; Desmundo, de Alain Fresnot; Brava Gente Brasileira, de Lúcia Murat.

Filmes históricos nascem de uma superprodução faustosa ou de um empenho intelectual e artístico exemplar e as duas categorias, tão discrepantes, têm função útil: a primeira fornece uma sucessão de cromos convencionais que correspondem, porém, a uma de nossas matrizes, a cultura cívica primária, enquanto a segunda suscita reflexão crítica a respeito do que fomos e somos. ${ }^{3}$

\footnotetext{
${ }^{1}$ ARISTÓTELES. Poética. São Paulo, Editora Nova Cultural 1999, p.45.

2 GOMES, Paulo Emílio Sales. Cinema: Trajetória no Subdesenvolvimento. São Paulo, Editora Paz e Terra, 1996, p. 72.

${ }^{3}$ Cinema: Trajetória no Subdesenvolvimento, p. 108.
} 
Quem somos? Talvez a História nos responda. E quanto mais recuarmos no passado, maior será nossa probabilidade de nos entendermos. Pelo menos é assim que funciona o mito das origens. Precisamos saber o começo de tudo para compreendermos onde chegamos e, talvez, para onde vamos. ${ }^{4}$

É pensando no cinema como instrumento de investigação da vida e da história e, ao mesmo tempo, como um meio de libertação do real, com possibilidades oníricas e políticas; que o roteiro cinematográfico $O$ Padre Voador talvez se distancie um pouco do atual contexto de produção, aparentemente mais preocupado com o presente, com a violência cotidiana das grandes cidades e a desigualdade social. A diferença também está na falta de perspectivas de um mundo melhor hoje. Talvez realmente não haja solução para o ser humano na Terra. Mas ao menos no cinema e nessa história que queremos contar, ainda há lugar para a imaginação, a possibilidade de o homem fugir da gravidade terrena e ganhar o céu.

O cinema brasileiro retomou o seu caminho, reencontrou público, foi reconhecido no Brasil e no exterior. Dez anos depois de Central do Brasil, de Walter Salles, ganhar o Urso de Ouro no Festival de Berlim, Tropa de Elite, de José Padilha, levou o Urso de 2008. O sucesso dessa história polêmica começou antes de sua estréia, com mais de 11 milhões de cópias piratas vendidas, em versão ainda inacabada do filme. Bráulio Mantovani, o roteirista, é o nosso único indicado ao Oscar de roteiro com Cidade de Deus, de Fernando Meirelles.

Bráulio Mantovani também é um dos vinte e cinco sócio-fundadores da associação de roteiristas que surgiu no final de 2006: Autores de Cinema, a AC. E um dos onze mil afiliados da Writers Guild of America, a WGA, que manteve uma greve por quatorze semanas em 2007, causando um prejuízo à indústria norte-americana do audiovisual de dois bilhões de dólares.

A paralisação dos roteiristas norte-americanos suspendeu sessenta programas de TV e adiou a produção de dezenas de filmes. Nem a festa do Globo de Ouro foi poupada. Mesmo assim, o apoio aos grevistas não foi visto só nos piquetes em Nova York e Los Angeles.

\footnotetext{
${ }^{4}$ Oricchio, Luiz Zanin. Cinema de Novo: um balanço crítico da Retomada. São Paulo, Estação Liberdade, 2003, p. 49.
} 
Pudemos apreciar atores famosos imóveis, roteiros em branco nas mãos e até um Woody Allen mudo à frente da câmera, nos vídeos que apareceram no You-Tube.

O assunto rendeu capa e matéria em jornais importantes. Bráulio Mantovani e Marcos Bernstein, da AC e WGA, foram entrevistados, elogiaram os colegas norte-americanos em sua segunda grande luta por mais direitos (a primeira foi em 1988) e aproveitaram para lembrar que os nossos problemas aqui no Brasil ainda são bem mais existenciais.

Somos ou não somos?

A profissão é mal conhecida e pouco reconhecida. O roteirista é o primeiro autor do filme, todo escrito por ele no papel, antes de ser lido pelos patrocinadores, atores, técnicos. É o guia do diretor, e disso não dão conta muitos espectadores.

A fotografia, a arte, a música do filme parecem ter mais espaço nos artigos sobre cinema, poucos críticos analisam o trabalho realizado pelo autor do roteiro; quando o fazem é freqüente sequer o chamarem pelo nome. Não vemos muitos roteiristas convidados para jurados nos festivais de cinema e quase nunca há um autor do roteiro nas cenas extras dos DVDs ou em making ofs.

Por quê?

Ao contrário dos autores globais de novelas e minisséries, os nomes dos autores de cinema, com algumas exceções, não costumam estar em destaque nos créditos que rolam nas telas, nos cartazes, releases e fichas técnicas comuns em sites especializados da internet.

No tempo da idéia na cabeça e da câmera na mão, o cinema de autor não era habitualmente escrito por um roteirista; criava-o o próprio diretor. Além das dificuldades econômicas e dos anos que consomem uma produção, não havia muitos profissionais especializados. 
A formação de um grupo de autores de cinema talvez tenha começado com maior força, no Brasil, a partir da retomada, nos anos noventa, e impulsionado pelo próprio Carlota Joaquina, princesa do Brazil, de Carla Camurati, com roteiro de Melanie Dimantas, da AC.

Já era, no entanto, amplamente reconhecido o trabalho de alguns poucos, como Orlando Senna, Leopoldo Serran, Doc Comparatto e Jorge Durán, um dos diretores da AC, mas grande parte dos sócio-fundadores da AC é uma ou duas gerações mais jovem.

A associação nasceu de um encontro entre colegas e amigos que, no lugar da resignação contraproducente, decidiram empenhar-se em defender o devido valor à profissão. Quem não é do meio chega a confundir a profissão de roteirista com a de guia de viagens, diz o primeiro presidente da AC, Di Moretti (autor de Latitude Zero, Cabra Cega).

Seria preciso explicar o que é a profissão do roteirista e o trabalho que ela exige. Queríamos que a importância do roteiro fosse conhecida pelo público, e legitimada mesmo entre alguns colegas produtores e diretores.

Pensando nessa necessidade de se fazer ver e ouvir, a AC promoveu, entre outros encontros, o seminário Roteiro em Questão I e II, nos últimos Festivais de Cinema de Brasília. Tive a oportunidade de participar de ambos. Em 2006, como roteirista convidada, pelo filme concorrente Batismo de Sangue, de Helvécio Ratton. Em 2007 participei da mesa nas conversas com Julio Bressane, autor do roteiro de Cleópatra; Carlão Reichenbach, de Falsa Loura; e Daniel Bandeira, de Amigos de Risco -- três diretores roteiristas de seus filmes; José Eduardo Belmonte, que escreveu Meu mundo em perigo com Mario Bartolotto e Luís Bolognesi, o único roteirista profissional, também da $\mathrm{AC}$, que levou o candango com Chega de Saudade, de Laís Bodanzky.

Talvez a média seja mais ou menos essa. De cada cinco filmes, apenas um é escrito pelo profissional, o roteirista, o autor de cinema. 
A presença da $\mathrm{AC}$ nos festivais de cinema tem como programação, no dia seguinte à exibição dos filmes, expor e debater a criação de cada roteiro, o ato da escrita de cada autor, os diferentes métodos de pesquisa e de trabalho. E tanto os roteiristas da AC como os convidados e o público em geral parecem concordar em uma 'unanimidade inteligente': a importância fundamental do roteiro cinematográfico no filme.

A busca de profissionalização do roteirista e da valorização de seu trabalho não se dá apenas entre os colegas do meio, na formatação de contratos, no estabelecimento dos direitos e deveres, prazos, remunerações ou créditos; mas também na mídia, com a divulgação da existência desse profissional e do seu importante - literalmente papel - na produção cinematográfica.

A Academia Brasileira de Cinema de 2008, de seu lado, reafirmou a tendência de premiar o roteirista profissionalizado. Marçal Aquino e Claudio Galperin, ambos da AC, foram os premiados em roteiro adaptado e roteiro original.

É nesse contexto, de ocupar o devido lugar, que esta tese-roteiro, um trabalho de criação, na e da prática, torna-se também uma proposta de diálogo entre roteirista e academia, normalmente mais voltada à pesquisa teórica.

O interesse em valorizar a formação técnica e artística do roteirista, como autor de cinema, não poderia encontrar melhor tempo e espaço do que esta Escola de Comunicações e Artes.

\section{A bolha no ar}

A história da criação do roteiro deste doutorado é longa. Foram oito anos de convívio descontínuo. Como outros tantos projetos cinematográficos, o filme talvez nunca seja realizado. A idéia era a estréia em 2009, trezentos anos depois que Bartolomeu de Gusmão fez voar o seu pequeno balão perante o rei e a corte portuguesa. 
Apesar de o Museu Paulista já ter dedicado uma sala só para o Voador, descobri sua existência ao ler Memorial do Convento ${ }^{5}$, de José Saramago, parte da bibliografia indicada na última disciplina optativa que cursei na graduação em Letras: Introdução aos Estudos Comparados de Literaturas da Língua Portuguesa, ministrada pelo professor doutor Benjamin Abdala Junior.

As empreitadas do Memorial de Saramago parecem impossíveis mas não são, talvez nada seja impossível quando o desejo utópico é uma vontade superior e quase inexplicável. O autor, que trabalhou vinte e oito anos em cima da realidade e do fantástico, comove com a narrativa e seu narrador camaleão. Pontos de vistas baixos, diversos, a experiência da alteridade nos vários personagens, as identidades que se criam longe da corte. O artista Saramago nos mostra a corte e a praça, foi onde o povo viveu e morreu.

A passarola do padre voador difere de muito o convento de Mafra, construído de suor e sangue, o fruto da vaidade de um antigo rei tirano em nada se parece com o sonho de toda a humanidade, a passarola de cada um.

A igreja da inquisição precisa destruir todos aqueles que não consegue domar, porém é incapaz de destruir a todos porque existem os que não estão sós, os que possuem o outro, a vontade do outro, os que voam, olham de cima para o labirinto e sobrevivem. ${ }^{6}$

Saramago faz ficção com fatos verídicos, no seu era uma vez, a história da dupla construção: o convento de Mafra e a máquina voadora, paradoxo entre a gravidade terrena e a ascensão utópica. A imagem da passarola de Saramago subindo ao céu transparecia uma epifania, instalou-me a idéia na cabeça, gênese do roteiro.

O invento é do padre Bartolomeu, quem o constrói é o soldado Baltasar, mas é Blimunda que o faz voar, a mulher que em jejum consegue ver por dentro de tudo. Com essa trindade faz-se luz sobre as trevas.

O que move a máquina é o mesmo éter que segura todas as estrelas. Capturado pelos olhos de Blimunda, o éter é feito da vontade do outro, da vontade de cada um, porque só a

\footnotetext{
${ }^{5}$ SARAMAGO, José. Memorial do Convento. São Paulo, Difel, 1983.

${ }^{6}$ Patarra, Denise. Desejos e misérias nas três margens de um mesmo continente. USP, FFLCH, 1999.
} 
comunhão de todos torna possível essa comovente concretização de um sonho imenso, a instalação da utopia.

A máquina estremeceu, oscilou como se procurasse um equilíbrio subitamente perdido, ouviu-se um rangido geral, eram as lamelas de ferro, os vimes entrelaçados, e de repente, como se a aspirasse um vórtice luminoso, girou duas vezes sobre si própria enquanto subia, mal ultrapassara ainda a altura das paredes, até que, firme, novamente equilibrada, erguendo sua cabeça de gaivota, lançou-se em flecha, céu acima. Sacudidos pelos bruscos volteios, Baltasar e Blimunda tinham caído no chão de tábuas da máquina, mas o padre Bartolomeu Lourenço agarrara-se a um dos prumos que sustentava as velas, e assim pôde ver afastar-se a terra a uma velocidade incrível, já mal se distinguia a quinta, logo perdida entre colinas, e aquilo além, que é Lisboa, claro está, e o rio, oh, o mar, aquele mar por onde eu, Bartolomeu Lourenço de Gusmão, vim por duas vezes do Brasil, o mar por onde viajei à Holanda, a que mais continentes da terra e do ar me levarás tu, máquina, o vento ruge-me aos ouvidos, nunca ave alguma subiu tão alto, se me visse el-rei, se me visse aquele Tomás Pinto Brandão que se riu de mim em verso, se o Santo Ofício me visse, saberiam todos que sou filho predilecto de Deus, eu sim, eu que estou subindo ao céu por obra do meu gênio, por obra também dos olhos de Blimunda, se haverá no céu olhos como eles, por obra da mão direita de Baltasar, aqui te levo Deus, um que também não tem a mão esquerda, Blimunda, Baltasar, venham ver, levantem-se daí, não tenham medo. ${ }^{7}$

O esboço da imagem de uma espiral talvez tenha surgido nesse momento, no girar sobre si própria, erguer a cabeça de gaivota e se lançar em flecha céu acima, e também desse movimento, que imaginei sair da pedra, princípio de tudo, o núcleo; passar por sua desintegração em terra, areia, a transição para o mar, para o além-mar; até chegar ao ar que é o céu, o infinito.

Pedra, areia, mar e ar eram os elementos que me vinham à cabeça, parecia-me que ao acaso. A espiral, o rabisco eleito como linha condutora da história que comecei a contar na dissertação de mestrado, sob orientação do mesmo professor Benjamin Abdala Junior.

Bartolomeu Lourenço nasceu por volta de 1685, na então chamada vila do Porto de Santos. Era o quarto filho de uma família de doze irmãos, sendo oito eclesiásticos. Estudou no Seminário de Belém, em Nossa Senhora do Rosário do Porto da Cachoeira, na Bahia.

\footnotetext{
${ }^{7}$ Memorial do Convento, p.196.
} 
Do reitor, padre Alexandre de Gusmão, mestre e protetor, Bartolomeu, seu irmão Alexandre (afilhado de batismo do jesuíta), sua irmã Joana e João Álvares de Santa Maria, o caçula, viriam a adotar o sobrenome.

Para as famílias pobres e numerosas da grande colônia portuguesa havia a perspectiva da carreira religiosa, que educava e formava, propiciando alguma posição social. Embora Bartolomeu tenha abandonado o noviciado da Companhia de Jesus, provavelmente porque percebeu que não era essa a sua vocação, parece que se ordenou na diocese de Salvador ou de Santos, antes de voltar a Portugal pela segunda vez, em 1708. O visionário percorreu um longo caminho de Santos a Lisboa, entre os pés no chão de terra do Brasil e a cabeça no balão de ar quente em Portugal.

Segundo o Dicionário da História de Portugal ${ }^{8}$, Bartolomeu Lourenço interessou-se desde cedo pelas ciências e suas aplicações práticas. Esteve em Portugal no ano de 1701, quando seu engenho e prodigiosa memória deram o que falar. Voltou já sacerdote em 1708 e matriculou-se na Faculdade de Cânones da Universidade de Coimbra. Supõe-se que, para dedicar-se às célebres experiências, faltou à terceira chamada.

No início de 1709 dirigiu uma petição a D. João V anunciando a descoberta de "um instrumento para se andar pelo ar da mesma sorte que pela terra e pelo mar". O privilégio solicitado foi concedido pelo rei no dia 19 de abril do mesmo ano. Nessa época, Bartolomeu teria escrito sobre as possibilidades da aeronáutica, no Manifesto Sumário para os Que Ignoram Poder-se Navegar pelo elemento do Ar.

O padre ganhou o apelido de Voador e versejadores dele troçaram. Sua máquina criou grande expectativa; para desviar a atenção dos importunos surgiu a gravura da passarola.

Mas a verdadeira aeronave seria um balão de ar aquecido. No dia 5 de agosto de 1709, numa sala do Paço e na presença de D. João V, a primeira experiência ardeu sem voar.

\footnotetext{
${ }^{8}$ SERRÃO, Joel. Dicionário da História de Portugal. Vol. 3. Porto, Livraria Figueiras, 1992, p.184, 185.
} 
No dia 7 ou 8, um novo artefato voador subiu quatro metros e meio, até o teto do salão. No dia 3 de outubro outro "instrumento de voar", lançado na ponte da casa da Índia, elevou-se a "bastante altura".

Bartolomeu inventara um aeróstato rudimentar (na segunda metade do século XVIII espalhou-se a lenda de que o Voador realizara, ele próprio, uma ascensão). Em viagem para a Holanda, em 1713, teria seguido com sua pesquisa sobre o vôo. Voltou a Lisboa em 1716. Em 1720 obteve grau de bacharel e doutor em Cânones na Universidade de Coimbra. Conquistou prestígio como pregador e homem de letras.

D. João V, que o estimava, nomeou-o acadêmico da recém-fundada Academia Real da História e fidalgo-capelão na casa real. Quis "fazer carvão de lama e mato" e descobriu uma "máquina ou modo de moer".

Em setembro de 1724 fugiu da Inquisição, pois seu nome aparecera envolvido em bruxaria. Adoeceu durante a viagem, morreu em Toledo, Espanha.

Na biografia sobre o martírio de Antônio José da Silva e de sua genealogia, o jornalista e escritor Alberto Dines escreve o códice do padre que sonha:

O padre-voador alinha-se na facção dos oprimidos ou opressores, é progressista ou reacionário, herege, devoto, bruxo, vieirista, molinista, cabalista ou simplesmente louco? De tudo um pouco. Gusmão foi ordenado pelo bispo d. Francisco de São Jerônimo, porque Santos, onde nasceu, pertence à sua diocese. Nada de extraordinário, muitos o foram. Por hora, o jovem sacerdote está em Lisboa, agraciado com um surpreendente alvará de sua majestade, El rei d. João V, que o leva muito a sério...

Recém-coroado, recém-casado, ansioso para fincar o pé na História, d. João V tem imaginação para vislumbrar as possibilidades do instrumento.

Alguma coisa desarranjou-se no tabuleiro dos desempenhos - aos malvados deveriam reservar-se todos os papéis estúpidos. D. João V, o gerente dos Autos de Fé e algoz de Antônio José da Silva, é o único a perceber o grande salto adiante. ${ }^{9}$

\footnotetext{
${ }^{9}$ DINES, Alberto. Vínculos do Fogo, São Paulo, Companhia das Letras, 1992, p. 605, 607.
} 
O instrumento imaginado por Bartolomeu Lourenço de Gusmão tornou-o precursor da aviação. É essa a tese que Afonso de E. Taunay defende em Bartolomeu de Gusmão ${ }^{10}$, um dos livros que escreveu sobre o padre voador, obra que me foi apresentada pelo cineasta Tom Job Azulay, diretor de $O \mathrm{Judeu}^{11}$, logo no inicio da pesquisa para a dissertação.

Na epígrafe da biografia, Afonso Taunay transcreve Camilo Castelo Branco, em carta de 1873, a Alberto Pimentel: "o sábio, o ilustre, o maior homem que a Portugal deu o século XVIII". A transcrição da carta de Camilo Castelo Branco segue no capítulo XXIV:

“A plebe de 1709, má porque ignorante, disse que o padre Bartolomeu era feiticeiro; mas os doutos, os poetas daquele tempo, que não acreditavam nos feitiços, perseguiram o padre com a irrisão, e depois com os quadrilheiros do santo ofício, porque ele, pactuando com o diabo, tecera as asas da Passarola, e afrontara a santa ignorância de frades e poetas, que nunca tinham ousado erguer-se acima da terra sem o auxílio de uma escada". ${ }^{12}$

Na introdução do livro, Taunay discorre sobre a vida do padre Bartolomeu, qualificando-a de gloriosa e trágica; ao mesmo tempo destaca os feitos que, segundo ele, revelam a sua importância:

Na galeria das nossas glórias nacionais, e nas do Novo Mundo, assim como na história universal da Ciência, primacial relevo assume Bartolomeu Lourenço de Gusmão, primeiro americano cujo nome, por ordem rigorosa cronológica, se incorpora aos fastos das conquistas científicas e a de uma das maiores vitórias jamais alcançadas pela Inteligência no terreno da Inventividade. Reservara-lhe, porém, o Destino, uma das mais fortes animadversões de que rezam os anais da humanidade. Fê-lo viver, evoluir e atuar num meio que lhe não podia compreender os raptos do talento. Não contente de o hostilizar ainda procuraria aviltá-lo, perante os contemporâneos e os pósteros. ${ }^{13}$

Nome de avião em Portugal, ruas em diferentes cidades, hangares de aeroporto, personagem de estátua e troféu, Bartolomeu de Gusmão é o Voador, amigo do rei.

\footnotetext{
${ }^{10}$ TAUNAY, Afonso de E. Bartolomeu de Gusmão. São Paulo, Edições Leia, 1942.

${ }^{11}$ O Judeu. Direção de Jom Tob Azulay. Brasil, Portugal, 1991.

${ }^{12}$ Bartolomeu de Gusmão, p.133.

${ }^{13}$ Bartolomeu de Gusmão, p.3.
} 
O início dessa história teria sido uma bolha de sabão a subir pelo impulso do calor e a possibilidade de transpor limites, de mais aproximar-se de Deus.

Relatou Bocous, um dos seus primeiros biógrafos, em 1817, que a idéia da construção do aeróstato lhe viera da observação do fenômeno dos mais vulgares, destes que a cada passo estão ao alcance de todos os humanos e, no entanto, só se tornam capazes de conseqüências fecundas quando observados, experimentados e regulamentados por inteligências aquilinas.

A Bartolomeu de Gusmão ocorreu a idéia do balão vendo uma bolha de sabão ascender, bruscamente, ao passar, por acaso, por sobre um foco calorífico. Do exame de tão insignificante fato decorrera a apresentação imediata, à sua poderosa mentalidade, de uma consequiência do mais elevado alcance. ${ }^{14}$

É bem provável que nem o biógrafo, no início do século dezenove, nem Bartolomeu no início do século dezoito, pudessem imaginar o alcance que tal idéia atingiu. A humanidade seguiu sua luta por mais poder, conquista de terras, exploração dos corpos e aniquilamento das almas, conseguindo transformar aquela bolha mágica em máquinas mortíferas altamente tecnológicas.

Instrumentos que, ao invés de servirem apenas para levar e trazer notícias, cargas, passageiros, acabaram por aprofundar ainda mais as tantas fendas que já dividem os seres humanos. Infelizmente podemos supor que o belo sonho de voar, livres como os pássaros nos parecem ser, já nasceu bélico: um dos argumentos que Bartolomeu usa, a justificá-lo junto ao rei D. João V, no começo do século XVIII em Portugal, é o de tornar mais rápidas as comunicações em batalhas.

$\mathrm{Na}$ dissertação tive oportunidade de comparar a representação literária do padre Bartolomeu Lourenço, nosso protagonista, escrita por José Saramago em Memorial do Convento, com a de Afonso de E. Taunay, autor de sua biografia mais importante.

Percebe-se que ambos os escritores valem-se de alguns textos e documentos em comum. Saramago aproveitase livremente daquilo a que teve acesso, Taunay parte em busca da comprovação de sua veracidade.

\footnotetext{
${ }^{14}$ Bartolomeu de Gusmão, p. 172.
} 
É assim que o romancista usa o próprio desenho e o memorial da passarola para construir a máquina de voar de seu padre Bartolomeu Lourenço ${ }^{15}$. Já o biógrafo prova que Bartolomeu de Gusmão espalhou essa sua "lucubração mistificatória" tentando garantir seus direitos sobre o verdadeiro invento, o "balão de São João". ${ }^{16}$

Para o crítico escritor José Saramago, o padre Bartolomeu Lourenço provém de uma terra do outro mundo, onde se evangelizam os tapuias e se arranca ouro e outras riquezas. Em sua visão anticolonialista ironiza o português e assume indubitavelmente a posição em favor do oprimido, representado por Blimunda e Baltazar. Para o nacionalista historiador Afonso de E. Taunay, Bartolomeu de Gusmão é um inventor brasileiro que tem a primazia do aeróstato, algo que lhe foi sonegado e que o biógrafo procura resgatar ${ }^{17}$.

Comprometido com a exaltação dos fatos e feitos, principalmente no reino português, Taunay projeta seu padre Bartolomeu Lourenço de Gusmão no exterior. Identificado com o estrangeiro, no luxo da corte, parece nem ter saudades de nossa terrinha. Figura nos eventos, protagoniza-os, mas não nos permite conhecer o seu interior. O didático narrador tem um objetivo e uma estratégia, irá resgatar o moral, a fama e os direitos de seu personagem, interrompendo sempre que necessário sua cadência de confrontação dos documentos, para defendê-lo de preconceitos e disparates.

Já o escritor José Saramago revê o padre brasileiro sob a ótica de um crítico do final do século XX, o narrador onisciente, que observa os fatos do século XVIII com uma lente panorâmica, entrelaça seu discurso à grande angular de seu personagem, aproximando-se dele como em um primeiro plano. E isso não ocorre apenas quando lhe dá a vez e a voz, ao sair da terceira para a primeira pessoa, mas também quando o representa como homem fragmentado que deve ter sido. ${ }^{18}$

Em 2002, depois de cumprir os créditos do Mestrado na FFLCH e na ECA, em São Paulo, lecionei na Faculdade de Cinema e Vídeo da UNISUL, em Santa Catarina. Decidi morar perto de Santo Antonio de Lisboa, onde ainda se ouve o português açoriano antigo. Sua igrejinha do século XVIII, as ruas de pedra e algum casario colonial, a praia e, no horizonte, o continente debaixo do céu.

\footnotetext{
${ }^{15}$ Memorial do Convento, p.92.

${ }^{16}$ Bartolomeu de Gusmão, p. 276.

${ }^{17}$ Patarra, Denise. O Padre Voador e sua representação literária por José Saramago e Afonso de E. Taunay. Departamento de Letras Clássicas e Vernáculas, FFLCH, USP, 2003, p. 3.

${ }^{18}$ O Padre Voador e sua representação literária por José Saramago e Afonso de E. Taunay, p. 66.
} 
Pedra, areia, mar e ar, reencontro meus elementos. A casa fica no topo de um morro no bairro do Sambaqui, praticamente dentro da mata atlântica. No final, passarinhos entravam e saiam à vontade do quarto onde escrevia. Estávamos na Ilha de Florianópolis ou Nossa Senhora do Desterro, onde Afonso de E. Taunay nasceu.

Foi a partir da leitura de Saramago e Taunay que dei início à criação do que então chamei de roteiro cinematográfico $O$ Padre Voador. De Saramago absorvi suas motivações libertárias e me agarrei ao vôo da passarola. Em Taunay encontrei a meticulosa pesquisa histórica dos fatos que marcaram a sua vida.

Na biografia, por exemplo, Afonso de E. Taunay afirma que Bartolomeu de Gusmão esteve uma primeira vez em Portugal, ainda adolescente, enviado pelo padre Alexandre de Gusmão, seu educador. A notícia sobre a "memória infra escripta" de Bartolomeu foi publicada por José Soares da Silva em a Gazeta em forma de carta, anexo, escrito por um anônimo: Memória das conclusões que offerece e promete defender Bartholomeu Lourenço, natural de Santos. Segundo Taunay, algum invejoso que procurou desmoralizar o jovem brasileiro.

Primeiro dirá de cor todo o Virgilio, Horacio, Ovídio, Quinto Curcio, Suetonio, Mecenas, Sêneca para diante e para traz, ou onde lhe apontarem. Dará a definição de todas as fábulas que se escreverão, e que fim a gentilidade as fingio; ponto que até aqui não se ventilou.

Dirá os emblemas do Alciato repetidos, e apontados, com o sentido próprio a qualquer cousa que venha em contrario aos livros clássicos.

Todos os livros de versos antigos, e modernos até o ano 1200 dirá quem são seus autores.

Toda a pessoa que lhe disser poesia alguma de repente promette responder ao mesmo intento com dez versos, e se forem mais, hirá elle multiplicando.

Promette defender toda a philosophia e os pontos mais intrincados della; e também explicar a parte de Aristóteles, com todos os seus embaraços, termos e meyos termos.

Promette para augmento da Santa Igreja responder a todas as duvidas da sagrada Escriptura do testamento velho, e novo, repetindo de cor todos os evangelhos dos quatro Evangelistas para traz e para diante; o mesmo de todas as epistolas de S. Pedro e S. Jeronymo, e explicar a dita escriptura nos quatro sentidos dos Doutores. Dizer toda a escriptura decoradamente; e as duvidas todas das lingoas em que foi escripta; e os annos que se intrometerão de Propheta a Propheta, quantos anos teve de vida hum delles, e o mesmo de todos os reys da Escriptura. 
E promete repetir para baixo e para cima os Livros dos Psalmos, dos Cantares do Êxodo, e todos os livros dos Reys; e sustentar por razões não serem canônicos os dois Livros de Esdras. ${ }^{19}$

Reconhecemos nessa "memória", o texto que se segue em Memorial do Convento, a obra de José Saramago:

Bartolomeu Lourenço, que no Brasil nasceu e novo veio pela primeira vez a Portugal, de tanto estudo e memória que, sendo moço de quinze anos, prometia, e muito fez do que prometeu, dizer de cor todo Virgílio, Horácio, Ovídio, Quinto Cúrcio, Suetónio, Mecenas e Sêneca, para diante e para trás, ou donde lhe apontassem, e dar a definição de todas as fábulas que se escreveram, e a que fim as fingiram os gentios gregos e romanos, e também dizer quem foram os autores de todos os livros de versos, antigos e modernos, até no ano de mil e duzentos, e se alguém lhe dissesse uma poesia, logo responderia a propósito com dez versos seus ali mesmo compostos, e prometia também justificar e defender toda a filosofia e os pontos mais intrincados dela, e explicar parte de Aristóteles, ainda que extensa, com todos os seus embaraços, termos e mais termos, e responder a todas as dúvidas da sagrada Escritura, tanto do Testamento Velho como do Novo, repetindo de cor, quer a fio corrido quer salteado, todos os Evangelhos dos quatro Evangelistas, para trás e para diante, e o mesmo das epístolas de S. Pedro e S. Jerônimo, e os anos de profeta a profeta e quantos de vida teve cada um deles, e o mesmo de todos os reis da Escritura, e o mesmo, para baixo e para cima, para a esquerda e para a direita, dos Livros dos Salmos, dos Cantares, do Êxodo e todos os livros dos Reis, e que não são canônicos os dois livros dos Esdras, como afinal não parecem muito canônicos, diga-se aqui para nós e sem outras desconfianças, este sublime engenho, estas prendas e memória nascidas e criadas em terra de que só temos requerido o ouro e os diamantes, o tabaco e o açúcar, e as riquezas da floresta, e o mais que nela ainda virá a ser encontrado, terra doutro mundo, amanhã e pelos séculos que hão-de-vir, sem contar com a evangelização dos tapuias, que só ela nos faria ganhar a eternidade. ${ }^{20}$

Com base nessa possível memória prodigiosa que ambos os escritores retratam, e inspirada por Camões, que imaginei Bartolomeu lendo, criei uma cena excluída na versão atual do roteiro:

\footnotetext{
${ }^{19}$ Bartolomeu de Gusmão, p. 34, 35.

${ }^{20}$ Memorial do Convento, p.62,63.
} 
INT - SALA DO PAÇO - DIA

O PRÍNCIPE se aproxima com um livro de Camões.

D. JOÃO

Também tens memória para aquilo que não conheces?

O PRÍNCIPE abre o livro em uma página qualquer e o entrega a BARTOLOMEU, que lê o poema, fecha o livro e, olhando nos olhos do PRÍNCIPE, declama.

\section{BARTOLOMEU}

Tanto de meu estado me acho incerto/ Que em vivo ardor tremendo estou de frio;/ Sem causa, juntamente choro e rio;/ O mundo todo abarco e nada aperto./ É tudo quanto sinto um desconcerto;/ Da alma um fogo me sai, da vista um rio;/ Agora espero, agora desconfio,/ Agora desvario, agora acerto...

BARTOLOMEU respira fundo e aperta o livro no peito. D. FRANCISCO acha graça e dá risada do poema.

\section{BARTOLOMEU}

Estando em terra, chego ao céu voando;/ Numa hora acho mil anos, e é de jeito/ Que em mil anos não posso achar uma hora... Se me pergunta alguém por que assim ando,/ Respondo que não sei;/ porém suspeito/ Que só porque vos vi, minha senhora.

BARTOLOMEU, sem-graça, devolve o livro ao PRÍNCIPE, que lhe sorri, encantado. BARTOLOMEU vê D. NUNO, que se aproxima e leva o PRÍNCIPE e infante embora. ${ }^{21}$

Dou-me conta hoje que aquela primeira versão do roteiro era ainda muito atrelada ao argumento. Essa percepção veio após a escrita de outros dois roteiros, entre 2003 e 2005, Batismo de Sangue, de Helvécio Ratton e Proibido Proibir, de Jorge Durán, ambos já produzidos e lançados.

\footnotetext{
${ }^{21}$ O Padre Voador e sua representação literária por José Saramago e Afonso de E. Taunay, p. 122.
} 


\section{Tanto mar}

No meio foi o sonho diurno. Houve a possibilidade de fazer o filme. Daí o prosseguimento no projeto com a re-criação de $O$ padre Voador, sob a orientação do professor Ismail Xavier, aqui na ECA, em 2006.

Em sua obra $O$ Princípio Esperança ${ }^{22}$, o filósofo alemão Ernst Bloch considera que o sonho diurno é um querer viver melhor, uma possibilidade a que se pode dar forma, que visa um ponto de chegada, uma realização, possui amplitude humana e, se quem sonha não está ilhado em seu entorno imediato, se o sonhador está além de si mesmo, então o sonho diurno busca a melhoria pública, as utopias sociais e, portanto, é um sonhar para a frente; ao contrário do sonho noturno, que se passa em regressão. O sonho diurno, que se estende ao longo de sua dimensão utópica, necessita de correção e concretização, tem um alvo e persegue sua direção; enquanto a esperança é um afeto prático, militante.

Contraditório, curioso, perspicaz, o padre Voador nunca perdeu a esperança de realizar o seu sonho diurno. Bartolomeu tenta concretizar um sonho que não é apenas dele, mas de todos nós. Voar é ser livre. É ganhar o espaço. A derradeira vitória sobre a força da gravidade. No seu tempo e caso, instrumento de fuga do Estado opressor e da Inquisição. O vôo simboliza a chegada ao paraíso, o encontro com a utopia.

Em ensaio de 1961, o historiador Eric J. Hobsbawm observa, sobre a obra de Ernst Bloch: “... não é todo dia que somos lembrados, com tanta sabedoria, erudição, inteligência e domínio da língua, de que a esperança e a construção do paraíso terreno são o destino do homem". 23

\footnotetext{
BLOCH, Ernst. O Princípio Esperança.

${ }^{23}$ Hobsbawm, E. J. Revolucionários. São Paulo, Editora Paz e Terra, 2003, p.145.
} 
Esse destino foi perseguido com convicção por Bartolomeu, um homem cujas idéias se projetavam para além de seu tempo. Desafiando os dogmas da Igreja para realizar o seu sonho, o Voador tinha idéias de cientista revolucionário. E, apesar do apreço do rei, levou fama de feiticeiro. Amigo de judaizantes, não se absteve de bajular o temido inquisidor geral, nem talvez de fugir, quando achou necessário; porque o padre inventor não queria morrer queimado na fogueira da Inquisição.

Dois séculos depois de Leonardo da Vinci e dois séculos antes de Alberto Santos Dumont, Bartolomeu de Gusmão acreditou que podia voar e foi em busca de D. João V para patrocinar seu invento mais importante, o aeróstato ou balão de ar quente, que fez dele um verdadeiro patrimônio cultural brasileiro e português.

Com a criação do roteiro $O$ Padre Voador há o empenho de contar um pouco da história desse homem e contribuir para manter viva a sua memória quase desconhecida; e para destacar a importância do sonho, da utopia, do princípio esperança, apesar dos nossos tempos de ceticismo sombrio.

Pode soar anacrônico, porém revisitar o sonho de voar de Bartolomeu no início do século vinte e um, e concretizar essa possibilidade em nossa história, é um querer de reafirmação da utopia.

Uma intenção necessária quando a humanidade parece caminhar para a crença irrevogável de que a utopia está morta, que se acabou o humanismo, que impera o egoísmo e a ganância no planeta chamado Terra, feito de água, cada vez mais à beira de um desastre humano e ecológico.

Embora a invenção do padre não objetivasse necessariamente a coletividade humana e, sim, os domínios da corte, o balão a voar no roteiro, a nosso ver, simboliza a vitória de um final feliz. 
O retorno ao encontro do padre Voador envolveu a visita, em Cachoeira, na Bahia, à igreja do Seminário de Belém, que parece manter suas características originais; enfileiradas de ambos os lados, como dois braços abertos, as velhas casinhas que formavam o colégio infelizmente se encontram bastante desfiguradas.

É aí que a trama se inicia, porém seu foco principal é além-mar, na Lisboa do reinado de D. João V e na atuação do inquisidor geral de Portugal, D. Nuno da Cunha Ataíde.

Em busca daquele mundo do século XVIII cumpri parte dos créditos obrigatórios do presente doutorado na FFLCH-USP, Departamento de História, em estudos sobre a Inquisição e o discurso da intolerância.

\section{A descoberta do fogo}

Os portugueses ainda desbravavam o Brasil quando a Inquisição se instalou em Portugal, em 1536, época de D. João III. Apesar dos tempos modernos, talvez haja uma única diferença em relação à Inquisição medieval: pela primeira vez é o rei quem nomeia o inquisidor-geral, e este, por sua vez, escolhe os membros do conselho da Inquisição, de acordo com o mesmo rei.

Hierarquia e fidelidade no terror, as trevas são eles. A cada década, século, mais obscurecidos pelas sombras das fogueiras, as cinzas. Em Lisboa também se queimam livros e panfletos, as idéias impressas dos exterminados. A legislação e os estatutos da Igreja e do Estado anulam direitos, discriminam, confiscam e excluem conforme os interesses econômicos e os fundamentos teológicos dogmáticos.

O caráter dualista do "Santo Ofício" nesse contexto é evidente: ele conserva sempre sua natureza de tribunal eclesiástico, devido à sua fonte principal de legitimidade e às funções atribuídas, mas é também um tribunal da Coroa, dados os mecanismos de nomeação e de enquadramento administrativo. 
Com efeito, a Inquisição está instalada em palácios da Coroa. Mas os bens dos tribunais pertencem explicitamente à Coroa, que se encarrega diretamente da percepção e gestão dos bens confiscados. ${ }^{24}$

Regimentos, atas e processos, pregações, sermões, manuais de missa e obras literárias estigmatizam, alimentam o preconceito da pureza de sangue, doutrinam o cristão-velho contra o cristão-novo, vão ao encontro de seus interesses sociais e econômicos, criam referências para anular o outro que é diferente. Os poderosos idealizam uma sociedade homogênea, una, pura, sagrada. Para alcançar o patamar elevado, é necessário haver o ser inferior, aquele que tem sangue impuro, infecto, o desvio.

As famílias hebréias, que não puderam esquivar-se a uma situação intolerável fugindo de Portugal, ainda, na sucessão dos tempos, mais de uma vez ergueram as mãos suplicantes para o supremo pastor e fizeram rolar o ouro nos covis da corrupção humana; ainda mais de uma vez souberam despertar ou comprar a compaixão e o favor da corte papal; mas os resultados estavam longe de corresponder aos esforços e sacrifícios. Podia por esse meio salvar-se algum raro indivíduo, ou retardar-se por alguns meses a torrente impetuosa da intolerância; mas o edifício da Inquisição ficava cada vez mais sólido e o terror e o silêncio que ela fazia em redor de si tornavam-se cada vez mais profundos. ${ }^{25}$

Os cristãos-novos também eram chamados de homens de nação ou homens de negócio. Muitos deles são ricos comerciantes convertidos, que competem com os camponeses que chegam às cidades e rivalizam com os burgueses católicos.

A nobreza e o clero contra os membros de uma raça indigna. Aos responsáveis por todos os males que atingem o reino e a fé católica, o auto-de-fé. Mito extrapolado, conflito institucionalizado, uma luta de classes.

O Santo Ofício se fortalece e se o pária é condenado, a queima do corpo transforma o pecado em pó. As futuras gerações herdam a infâmia marcada no sambenito, o nome do tataravô herege estampado na igreja local, para sempre.

\footnotetext{
${ }^{24}$ BETHENCOURT, Francisco. História das Inquisições. São Paulo, Companhia das Letras, 2000, p.293.

${ }^{25}$ HERCULANO, Alexandre. História da origem e Estabelecimento da Inquisição em Portugal. Porto Alegre, Editora Pradense, 2002, p. 449, 450.
} 
O sangue infecto do judeu amaldiçoado persegue os descendentes mais longínquos, impede o acesso a algumas profissões como a medicina e a botânica, aos cargos públicos, a ordens militares, ordens religiosas e colégios.

Aqueles que são casados com cristãos-velhos, quando podem, pagam para tentar comprovar a limpeza de sangue de sua família.

Como grupo dominante e participante das forças de poder, posição que lhes garantia uma série de privilégios e honrarias, a Igreja utilizou-se de todos os meios possíveis para fortalecer sua imagem de propagadora e conservadora da Fé Católica. Não podemos deixar de ressaltar que, nos bastidores, persistia o interesse econômico, com enfoque na riqueza dos burgueses cristãos-novos. Todavia, os judeus e seus descendentes não foram os únicos discriminados pela Igreja Católica. Forte preconceito racial incidiu também contra outros grupos como: o mouro, o mourisco, o negro, o indígena e o cigano. ${ }^{26}$

Nos dicionários do século XVIII, infecto é quem tem judeu, mouro, negro, índio no sangue. Do índio e do negro dizem que são infiéis, muito inferiores, que não são humanos. Para salvá-los do que eles chamam de trevas, para evitar que comam carne humana, que se revoltem ou se misturem com os brancos, só a luz da verdade católica, a catequese, o batismo. É para submetê-los ao evangelho que os jesuítas se esforçam na colônia. Querem o índio segregado, livre, porém sujeito incondicionalmente ao missionário.

Contraditoriamente, os padres ensinam que o escravo africano não tem nenhum direito, apenas a brandura de seus senhores ricos pode salvá-los. A batalha é difícil.

... os costumes indígenas e negros nada puderam contra o núcleo europeu de cultura, que a língua e a ética expressaram: os jesuítas "levantaram uma barreira à desintegração da herança cultural de que eram depositários e de que foram, na colônia, os mais autorizados representantes e os propagadores mais ardentes. As águas que colheram nas fontes da Igreja e nas tradições da Metrópole e que fizeram derivar das altas cumeadas de seus colégios, derramaram-se pelas duas vertentes -- a das senzalas e a das aldeias de índios.

${ }^{26}$ CARNEIRO, Maria Luiza Tucci. Preconceito Racial em Portugal e Brasil Colônia. São Paulo, Perspectiva, 2005, p. 126, 127. 
Embora não tenha chegado com todo o seu esforço a neutralizar as influências que foram enormes, das duas culturas -- indígena e, sobretudo africana, a mais próxima e penetrante, é certo que conseguiram contê-las bastante para que a unidade cultural não se dissolvesse ou quebrasse sob a pressão permanente de uma extraordinária diversidade de elementos heterogêneos". ${ }^{27}$

Essa nova sociedade que se forma do lado de cá será dividida pela cor de sua gente. Social, política, econômica e culturalmente alheio está o povo comandado daquele que comanda e é letrado. O verbo será o português, o trabalho é do escravo e o padre não passa de um funcionário dependente economicamente.

Estamos no início do século XVIII, está consolidada a ocupação portuguesa no Brasil. Com o império lusitano e os domínios da fé católica expandidos, terá início o reinado de D. João V. A colônia serve muito bem à metrópole. A exploração de nossas riquezas sustenta o absolutismo português e a Inglaterra mercantilista. Grandes propriedades produzem o açúcar, as minas logo irão fazer jorrar ouro, pedras preciosas, diamantes, e, já que os índios não deram conta, os negros fazem o serviço enquanto o jovem rei corrompe e gasta à vontade.

O ouro do Brasil dá para tudo: encobre a debilidade da economia e paga os déficits do comércio, arma o exército de funcionários e veste os fidalgos, permite o luxo dos palácios e a grandeza dos monumentos...

O falso rei-sol D. João V (1707-1750), opulento sobre um país miserável, não sentira que sua corte e sua coroa se formaram do brilho do ouro e não do ouro, que este era da Inglaterra. ${ }^{28}$

O historiador português Oliveira Martins descreve D. João V carola, balofo, emproado, a peruca majestosa, o pulso repleto de rendas. O soberano pervertido desbaratou a riqueza da nação. Não regateava o preço das coisas, rico sem saber como, o rei brasileiro imaginava espantar o mundo com o modo perdulário com que dissipava. Mão sobre a bengala, risonho de si, passeando os olhos pela sua Patriarcal, o reino e a corte.

\footnotetext{
${ }^{27}$ FAORO, Raymundo. Os Donos do Poder. Rio de Janeiro, Editora Globo, 1884, p 201, 202.

${ }^{28}$ Os Donos do Poder, p. 227.
} 
Essa ópera contava quase quatrocentos figurantes. Afora o patriarca, tinha vinte e quatro principais, setenta e dois prelados, vinte cônegos, setenta e três beneficiados, mais de trinta mestres de cerimônias, acólitos, capelães. Custavam todos trezentos contos ao ano. E, além disso, cento e trinta cantores e músicos, por trinta e oito contos. E por cima, as rendas principescas do patriarca. E mais ainda o preço incalculável das festas magníficas, como o cenário deslumbrante de ouro, pedrarias, veludos, rendas, luzes, em nuvens de incenso despedidas pelos turíbulos cinzelados. ${ }^{29}$

Contas a pagar, o progresso econômico de parte da colônia não poderia deixar de despertar o interesse dos inquisidores: a maioria dos prisioneiros do Brasil são os cristãos-novos, com bens a confiscar.

Paralelo às ordens da igreja, há a coexistência de mundos diversos nas reminiscências das culturas originais dos negros, mulatos, índios, mamelucos e judeus. As proposições heréticas ou blasfêmias, a feitiçaria, as gentilidades, a sodomia e bigamia recebiam penas mais leves, como as galés. Praticar em segredo a religião judaica é considerado crime grave, os acusados têm todos os seus bens seqüestrados e recebem como sentença o cárcere e o hábito penitencial perpétuo. Ou a pena de morte na fogueira.

Entre os brasileiros perseguidos na primeira metade do oitocentos, sobressaem três brilhantes inteligências; dois padres, Bartolomeu Lourenço de Gusmão - considerado hoje precursor da aeronáutica - e o judaizante João Álvares de Santa Maria, ambos irmãos de Alexandre de Gusmão, o secretário de D. João V. Foram íntimos colaboradores da idealização do Tratado de Madri e, segundo Jaime Cortesão, eram de origem judaica. O terceiro, o famoso poeta e dramaturgo Antônio José da Silva - cognominado "O Judeu"-tem sido freqüentemente estudado, mas ainda não devidamente entendido. Os três faziam parte do grupo de estudantes subversivos brasileiros da Universidade de Coimbra. ${ }^{30}$

Jaime Cortesão observa que havia um sentimento de pátria própria radicado no grupo dos brasileiros natos, que se espalhavam não só pela Universidade de Coimbra e o claustro dos conventos, mas por toda Portugal. Eram os estrangeirados pela formação peregrina ou por contágio.

\footnotetext{
${ }^{29}$ MARTINS, Oliveira. História de Portugal. Lisboa, Guimarães \& C. Editores, 1977, p.237.

${ }^{30}$ NOVINSKY, Anita. Inquisição: prisioneiros do Brasil. Rio de Janeiro, Expressão e Cultura, 2002, p. 42.
} 
Cronologicamente, Bartolomeu de Gusmão teria sido um dos primeiros, ao traduzir no sermão que dedicou a Nossa Senhora do Desterro, padroeira dos emigrados, o sentimento coletivo e saudoso dos brasileiros que viviam em Portugal e dos estudantes que o ouviram em Coimbra.

Difficultosa e admirável resolução a que impelle ao exílio! Quem há que vendo o Sol voltar todos os annos, á mesma casa de onde sahiu, e vendo se fora da sua o não combatam as saudades da pátria?...

Porque hei de viver tantos annos desterrado? Que peito há, tão de bronze que não arrebente de dor e saudade?...

Assim busca a sabedoria, quem conhece o seu preço. Assim lavra uma coroa de glória e immortalidade a si e a esta Universidade, quem a vem buscar por tantos e tão evidentes perigos. ${ }^{31}$

Havia dois ideais secretos entre os estrangeirados: o das nações mais livres, já realizado na Europa e o de uma nova nação livre, a realizar-se na América.

Pertencem todos, ainda que por formas muito diferentes, a uma literatura de desencanto e inconformismo. Inconformismo queixoso, abstração do meio, crítica do regime, desilusão de quem sonhara outra metrópole. Não é difícil descortinar nesse grupo uma consciência alvorescente de pátria, que analisa, compara e se elabora. Estrangeirismo de luso-brasileiros, a quem não se esconde o particularismo próprio, duplicado nalguns, como os dois Gusmões. ${ }^{32}$

Cortesão se refere a Bartolomeu e Alexandre. Segundo o historiador português, ambos possuem traços comuns na dupla ascendência tupi e hebraica, a primeira certa e a segunda possível: inquietação, quase nômade; instabilidade moral ou de fé; tendência à elaboração ideativa e à expressão literária, escrita ou verbal; uma excepcional agudeza de entendimento e capacidade criadora e a queda para atitude mística na vida.

\footnotetext{
${ }^{31}$ Bartolomeu de Gusmão, p. 70.

${ }^{32}$ CORTESÃO, Jaime. Alexandre de Gusmão e o Tratado de Madri. Parte I, Tomo I, Rio de Janeiro, Instituto Rio Branco, s/d, p. 107.
} 
Embora nunca tenha sido comprovada a ascendência da "raça infecta", o "rumor contrário" veio em 1724, com a denúncia em processo contra vários judeus que viviam em Lisboa, a maioria do Rio de Janeiro. Entre eles, implicado em práticas judaizantes, Bartolomeu de Gusmão.

Frei João Álvares de Santa Maria, irmão caçula de Bartolomeu, que o acompanhou na fuga no final de setembro do mesmo ano, teve processo instaurado pelo Tribunal do Santo Oficio em Madri. Seu longo depoimento, escrito naquele mesmo ano, foi encontrado no Arquivo da Torre do Tombo pela pesquisadora portuguesa Berta Leite.

Desta vez cessaram as dúvidas. Duas conclusões principais, a avaliar aquêle transunto, podem tirar-se desse inesperado documento: pelo menos desde 1722, Bartolomeu de Gusmão judaizava e tinha arrastado com o seu ascendente a igual apostasia, seu irmão mais novo; além disso, desde maio de 1724, quando menos, a sua nova crença complicava-se com um delírio de grandezas, em que avultavam o inventor e o místico, fundidos nas mesmas megalomanias. Por esse documento se averigua, que Bartolomeu, inventor do aeróstato, sonhava agora criar uma máquina voadora, à qual atribuía, com profética visão, capacidades imensas de domínio. ${ }^{33}$

Afonso Taunay traduziu e publicou trechos do relato de cem páginas que teria sido escrito por Frei Santa Maria, em janeiro de 1725, nos autos do processo 15. 598 da Inquisição de Madri, descoberto por Berta Leite.

Resvalando agora para a apostasia a mais completa declarara o Voador negar os mistérios da Encarnação e da Santíssima Trindade. Nada provavam os argumentos do Velho Testamento, invocados pelos católicos em apoio de suas crenças. Negava ainda a existência do Espírito Santo e a Virgindade de Nossa Senhora, apoiado em Isaias. Tão pouco cria nas penas eternas e na queda dos anjos maus do Paraíso...

Afinal the conseguira Bartolomeu a apostasia, pois a ele por completo dominara. Passara a guardar os sábados, a não venerar as imagens sagradas, a mofar dos santos...

Pensara até em compor livros defendendo a lei mosaica. Fazia Bartolomeu questão de desrespeitar o mandamento da Igreja relativo à abstinência de carne às sextas-feiras e timbrava em obedecer aos mandamentos talmúdicos a tanto arrastando a sua vitima.

${ }^{33}$ Alexandre de Gusmão e o Tratado de Madri, p.131, 132. 
Completamente divorciado do estado sacerdotal e a ele, Fr. João vendo apostata do seu estado religioso resolvera o Voador deixar Portugal, arrastando o rapazola...

Haviam-se os dois posto em marcha “ por la presumpcion de que eran outro Pueblo de Israel por El Desierto". ${ }^{34}$

Taunay conclui que o grande esclarecimento que o relato encontrado por Berta Leite nos traz é sobre a saúde mental do Voador em seus últimos meses de vida. Segundo Santa Maria, Bartolomeu dizia ser o messias, que iria dominar o universo com a sua máquina voadora, subjugando os monarcas da Terra e entregando o domínio do mundo aos israelitas.

Durante a fuga da Inquisição portuguesa, que durou quarenta e cinco dias e quinhentos quilômetros, Bartolomeu entremearia as tais heresias com arrependimentos, sonhos e dúvidas também quanto à fé no judaísmo.

Os nomes escolhidos por Bartolomeu na rápida clandestinidade, Miguel Santos para ele e Gabriel Santos para Santa Maria, são os mesmos nomes do anjo combatente e do anjo anunciador na tradição judaico-cristã. Miguel Santos também é o messias identificado pelo profeta Daniel.

Aqui do século XXI, apesar da seriedade com que foi divulgado, confesso que desconfio de tal depoimento prestado voluntariamente por Santa Maria aos inquisidores espanhóis do século XVIII. É sabido que antes mesmo de serem delatadas, muitas pessoas se apresentavam ao Tribunal para confessar atos que não haviam cometido por temor ao Santo Oficio.

Será que podemos garantir a veracidade às informações relatadas?

Temos certeza quanto à legitimidade de um discurso feito sob o domínio do medo e da tortura?

\footnotetext{
34 TAUNAY, Afonso de E. "A estranha aventura de Frei João Álvares de Santa Maria de Gusmão, carmelista santista (1724)" in Revista do Instituto Histórico e Geográfico de S. Paulo, volume XLIV, 1948, p.239, 240.
} 
É perfeitamente possível que Bartolomeu duvidasse do Espírito Santo e da virgindade da mãe de Jesus, que tivesse fé em um único Deus e em nenhum santo; mas não nos parece muito verossímil que ele, antes de morrer, acreditasse em ser o messias. Talvez esse fim patético e de certa forma remetendo à insanidade não combine com a imagem que fizemos do padre voador, com seu vôo final feliz no balão.

Um enlouquecido Bartolomeu de Gusmão, levado por coiotes como os atuais fugitivos de tantos países, é a negação do princípio esperança, o fim do sonho ou o verdadeiro pesadelo. Embora a utopia pareça não ter vez na história humana, que se perpetua a reiterar apenas o tópos trágico, a nossa escolha não é pelo mártir e o conflito irreconciliável de seu projeto naquelas condições históricas.

Optamos por um Bartolomeu quase alegórico, realizado no âmbito da imaginação, representante de um espírito de luz no obscurantismo. Um Voador em busca de um mundo melhor, longe das fogueiras feitas pelos homens e dos furacões determinados pela natureza, mas comumente interpretados como ira divina.

Citação de Walter Benjamin no livro de Carlo Ginzburg: "Nada do que aconteceu deve ser perdido para a história, só à humanidade redimida o passado pertence inteiramente". 35 Redimida, acrescenta Ginzburg, quer dizer liberada. Benjamin nos incita a esmiuçar toda a história e ainda ensina que tão-somente seremos livres se tomarmos posse do próprio passado.

Por mais vergonhosos que sejam, é preciso reconhecer os temas relativos à intolerância humana, ao fanatismo, às perseguições, aos extermínios, e sobre eles refletir.

Por meio da história de Bartolomeu de Gusmão contamos um pouco do que nos sucedeu. Por guia, o sonho diurno e a perspectiva da esperança.

\footnotetext{
${ }^{35}$ GINZBURG, Carlo. O Queijo e os Vermes. São Paulo, Companhia das Letras, 2001, p. 34.
} 


\section{Terra à vista}

Com a possibilidade de uma co-produção portuguesa, argumento enviado e convite aparentemente aceito, fomos ao encontro do cineasta Manoel de Oliveira que, em dezembro de 2006, acabava de completar 99 anos. O cineasta mais velho em atividade do mundo enfatiza que a originalidade consiste na personalidade do autor.

Para o mestre, a marcação é fundamental: o ator deve fazer isso ou aquilo, menos, mais e pronto: "O ator quando se esquece que é ator é ótimo. Tem uma nobreza muito grande quando nunca representa a si mesmo, mas a alma do outro. No teatro é o corpo do ator, no cinema só o personagem."

Manoel de Oliveira nos mostrou alguns de seus últimos guiãos. Perceptível como era sucinto nas ações e parece-me que indicava todos os diálogos. O cineasta denomina decupagem aquilo que chamamos de tratamento.

Essas correções de roteiro me pareceram pequenas, tive a impressão de que ele sabe, desde o princípio de um projeto, o que fará no final. Em seus roteiros, como bem lembrou Carlos Reichembach no Seminário Roteiro em Questão II, do Festival de Brasília de 2007, ele coloca até o tempo de cada cena.

Acredito que Manoel de Oliveira nunca filmou um guião de outra pessoa. Deixou claro que não trabalharia junto comigo no roteiro; poderia até aceitar o argumento, mas a decupagem, ou seja, o tratamento seria só seu.

Logo na primeira seqüência do primeiro tratamento do roteiro que levara para lhe mostrar, a câmera vinha do céu, revelando Lisboa do alto. Bartolomeu, em uma janela do Paço, ouvia alguém, em off, que o chamava. 
Manoel de Oliveira começou sua aula dizendo que "essas coisas não se escrevem em um roteiro, quem decide onde botar a câmera é o realizador; e off onde? Quem chama está sentado ou de pé?"

Tentei explicar que a câmera vinha do céu como se fosse o ponto de vista de um pássaro, que o filme também terminava no céu, mas que, enfim, não era tão importante assim e poderíamos tanto tirar a cena do céu como o off.

Manoel de Oliveira também era contra os sonhos de Bartolomeu. Disse que o cinema não pode filmar passado, pensamentos, sonhos. Só o presente, que é eterno. Ele considera que a teoria ilude e que o concreto não é teórico.

Disse que as escolas de cinema ensinam a técnica, que a técnica é ciência e a ciência é o domínio das leis da natureza. São pobres criaturas, não criadores. A técnica é o circo, são os malabarismos, não é arte. Já o artista não precisa da técnica e não precisa ser político, ele tem a expressão e o dom, que não se ensinam.

O mestre foi irredutível em uma questão, para mim crucial: o filme não poderia ter o vôo de Bartolomeu no final, porque a história não foi assim. Segundo ele, o artista mostra os resultados, não inventa: “Colocar o homem a voar é circo".

Tirar o vôo de Bartolomeu do filme?

A espiral a levar a pedra que se transforma em ar, a utopia?

Queríamos realizar o sonho, afirmar o princípio esperança, o otimismo, a crença na transformação e, quem sabe, na melhoria do mundo.

Sem o balão?

Claro que a fuga real de Bartolomeu por terra seria um final real e possível, porém triste e sem esperança. 
É instigante saber que ele se declarou o messias e depois enlouqueceu como declarou seu irmão aos inquisidores. Mas não é assim que termina a história que eu quero contar.

No dia seguinte à conversa com Manoel de Oliveira, em Porto, onde mora com sua família; fomos a Guimarães, na província do Minho, onde nasceu o pai de Bartolomeu, Francisco Lourenço, assim como a maioria dos portugueses que emigraram para o Brasil.

A caminhar em ruas tão antigas, a subir pelas ruínas de fortificações, a visitar o castelo de pedra, o convento. Uma busca por entrar na história.

Em Lisboa, o Arquivo da Torre do Tombo e o cheiro dos livros que restam para se tocar. Emocionante descobrir o desenho da passarola e sua descrição, os processos de Maria Coutinho e Miguel de Castro Lara.

\section{O desembarque}

Generoso orientador, Ismail Xavier fez a leitura do primeiro tratamento do roteiro e foi crítico e construtivo. Ofereceu diversos comentários esclarecedores sobre o trabalho.

O mais importante talvez seja o do fazer poético não só na palavra, mas também na imagem. Significa que faltam respiros. É preciso procurar os enxertos para a imaginação, a liberdade, a poesia e a invenção como oposição ao mundo do poder.

Seria bom aprofundar os elementos, porque a fronteira entre a magia e a ciência é tênue. E tentar criar mais justaposições, escapar da estrutura linear, para o espectador não se acomodar, saber tudo o que vem. 
Apesar de imaginar seguir uma espiral como linha condutora da história, parece que temos uma estrutura linear, causas e conseqüências, sem surpresas.

Em abril de 2007, na banca de qualificação, tive o privilégio de ouvir as opiniões dos professores doutores Flávio Aguiar da FFLCH e Roberto Moreira da ECA sobre o mesmo tratamento do roteiro.

Flávio Aguiar, por ser professor da Letras, falou primeiro. Disse que o roteiro parece uma peça de teatro. É necessário incrementar a parte cinematográfica, dar mais visibilidade. Penso no que Ismail disse sobre o fazer poético na imagem.

Flávio Aguiar nota que é preciso desenvolver mais as tensões entre os personagens. D. Nuno é o vilão, tem que ter ascendência. O rei é o monarca do império, mas o poder não é só seu, sua ambigüidade deve ser mais trabalhada. Na corte, que era muito regrada, falta solenidade, pompa, seguir os protocolos.

Também lembrou que o mundo está desabando e eles desconhecem o mundo que se infiltra. A mandrágora é uma flor afrodisíaca. A serpente pode significar a morte ou a cura, depende da dose, como o arsênico.

Roberto Moreira, além de professor, cineasta e roteirista, apontou como primeiro problema o começo muito expositivo e a falta de tensão dramática.

Disse que o roteiro só pega na página 46, com D. Nuno. E se ele estivesse na história desde o começo? D. Nuno é o vilão, mas por que e como?

Lembrou que a biografia tem unidade, a vida não, é espalhada. A parte pelo todo. Propõe começar depois e voltar em flash-backs. 
Acha que o caso das mulheres esvazia o padre. Existe suspense potencial no fim, mas tanto a ameaça da Inquisição como a dúvida sobre o que vai acontecer com Bartolomeu deveria permear mais a história toda.

Propôs-me entender a visão de mundo do D. Nuno, suas convicções e razões. Talvez a família judia também devesse aparecer desde o começo, ela é importante para mostrar a Inquisição.

Acrescentou que nas conversas de Bartolomeu com o rei precisamos sentir o bafo inquisitorial, porque no final tudo queima. $\mathrm{O}$ medo tem que ser dele. As freirinhas ou alguém deve ir para a fogueira. D. Nuno não pode abdicar de perseguir Bartolomeu no final.

Roberto Moreira sugere ainda que, como o balão libera da história, poderíamos ter mais vôo e carregar no drama. Ainda pergunta se os motivos do roteiro são apresentados no roteiro. E considera tratar-se de roteiro clássico e linear.

Lembro da estrutura linear apontada por Ismail Xavier. Causas e conseqüências, coerência demais talvez.

Com base nessas críticas e apontamentos, deu-se a escritura do segundo tratamento do roteiro. Ao rever as motivações das cenas e sequiências durante esse novo trabalho, pude perceber como algumas cenas eram desnecessárias ao enredo e como outras estavam fora de lugar. Aquelas cortadas, essas mudadas de ordem, e ainda acrescidos certos detalhes que faltavam, segue-se uma breve descrição de seus três atos:

O primeiro ato, que chamei de Seminário, é composto de duas grandes sequiências: a primeira invenção e as descobertas. O segundo ato, chamado Além-mar, é composto de quatro grandes seqüências: a viagem, a petição, a perseguição e o embruxamento. $\mathrm{O}$ terceiro ato é composto de uma única seqüência final: Fuga. 


\section{Capítulo 2}

\section{A Escavação:}

Roteiro Cinematográfico O Padre Voador 
Ainda está escuro.

Homens encapuzados em fila carregam pilhas de livros até o centro da praça onde uma grande fogueira já consome muitos livros, quadros, instrumentos de alquimistas, desenhos, esquadras, pincéis, ampulhetas, compassos, pedras, metais.

Enquanto os homens alimentam ainda mais a fogueira com os livros que trazem, D. NUNO DA CUNHA ATAÍDE, 40 anos, futuro cardeal e inquisidor-geral, alto, sisudo, observador e sempre muito sério, observa com o olhar satisfeito e sinistro.

Começa a amanhecer, D. NUNO sai seguido pelos homens.

Do outro lado, surge uma mulher de mãos dadas com uma menina, é CATARINA SALEMA, 37 anos, longos cabelos negros e BRITES MARIA, 10 anos, sua filha. Elas se aproximam da fogueira onde ainda restam alguns livros e objetos queimando.

\section{CATARINA}

Vês? Ainda há fogo.

\section{BRITES MARIA}

Fogo queima.

Enquanto a mãe resgata uma balança da fogueira, BRITES MARIA se ajoelha no chão e cava com as duas mãos. A menina amassa a terra que tirou do buraco com as mãos, como se fizesse um pão. CATARINA se aproxima com a balança e a enrola em um pano, faz sinal para irem embora.

\section{BRITES MARIA}

A terra...

BRITES MARIA joga a terra tampando o buraco e bate com as mãos sobre ele desfazendo qualquer sinal de que existiu. 
o céu está roxo, lilás e vermelho.

Sobre a imagem: CRÉDITOS INICIAIS.

Surgem nuvens que passam rapidamente. Abaixo do céu, o mar está bravo, venta.

A praia está deserta. Ouve-se sons de pássaros.

Sobre uma grande pedra à beira do pequeno lago, BARTOLOMEU 15 anos, um noviço jesuíta magro, bem moreno, olhos grandes e escuros, ouve o galo anunciando o amanhecer e observa os pássaros que voam e cantam sobre o brejo.

BARTOLOMEU tira pedras do bolso e joga na água, uma de cada vez, elas afundam.

Começa a ventar.

Chega MARIA, 17 anos, linda, mulata, olhos verdes, com uma tina na cabeça e dois baldes na mão. Ela vê BARTOLOMEU jogar uma pedra chata e clara, que não afunda, fica sorrindo para ele.

Venta forte.

BARTOLOMEU vê MARIA, abre os braços, respirando fundo com a boca e o nariz, sorrindo para ela.

\section{BARTOLOMEU}

Ar!

(alto)

Ar da manhã!

Ela ri dele. 
MARIA

Estás doido...

BARTOLOMEU abaixa os braços, fica sério.

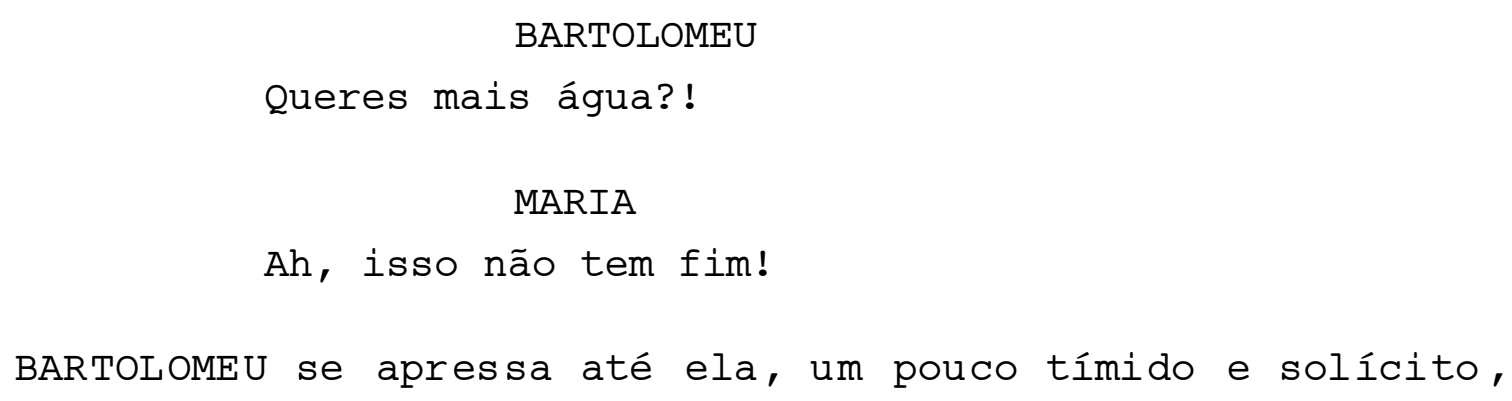

BARTOLOMEU segue MARIA com os baldes cheios de água nas mãos. Tina na cabeça, MARIA pára e espera até ele chegar ao seu lado, eles se olham e sorriem, aí andam de novo. BARTOLOMEU deixa ela ir na frente novamente, ela pára, espera, ele chega, sorriem e andam.

Vão indo assim, nesse lento pega-pega, até a porta da cozinha.

BARTOLOMEU entrega os dois baldes cheios para ANTÔNIA, 40 anos, mãe de MARIA, negra, escrava cozinheira.

\section{ANTONIA}

Já estavas afora?

BARTOLOMEU disfarça e dá uma olhada marota para MARIA.

\section{BARTOLOMEU}

Encanta-me ver o dia nascer. 
ANTONIA

Padre João num gosta quando vosmicê nem está na capela.

\section{BARTOLOMEU}

Tenho afazeres mais importantes.

\section{ANTONIA}

Do que rezar?!

MARIA, que retira a água da tina sobre a mesa, vê BARTOLOMEU, sorrateiramente, pegar um pedaço de bolo antes de sair.

Há poucas carteiras, a sala é muito grande para os dez SEMINARISTAS sentados de frente para O PADRE JOÃO, 50 anos, calvo, gordo, estendido como uma estátua zangada, braços cruzados.

DIOGO, um dos rapazes, lê um trecho do Novo Testamento enquanto os outros acompanham a leitura com a Bíblia aberta nas mãos.

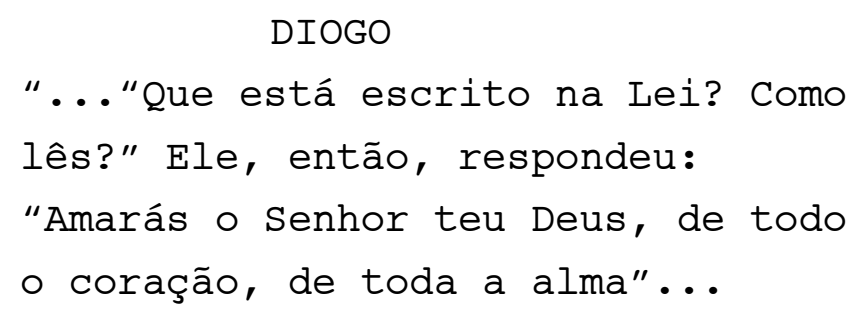

BARTOLOMEU é o único que não presta atenção, faz contas em seu caderno, que está sobre o livro.

O PADRE JOÃO se aproxima de BARTOLOMEU, irritado, pega o caderno e lê alto.

PADRE JOÃO

460 palmos igual a 101 metros... o

que significa isso? 


\section{BARTOLOMEU}

Estava entretido com outros

pensamentos...

PADRE JOÃO

Isso estou a ver. Acaso sabes do

que estávamos a falar?

BARTOLOMEU

Diogo lia o grande mandamento, por

Lucas.

PADRE JOÃO

$\mathrm{E}$ tu sabes em que parte estávamos?

BARTOLOMEU sabe de cor e salteado, não precisa ler.

BARTOLOMEU

"Com toda tua força e de todo o entendimento; e a teu próximo como

a ti mesmo." Jesus disse:

"Respondeste corretamente; faz isso

e viverás."

BARTOLOMEU sorri para PADRE JOãO •

BARTOLOMEU

Também eu respondi corretamente.

$$
\text { (irônico) }
$$

E se quiseres, digo-o todo de trás para diante, sem ler.

PADRE JOÃo não gosta nada de sua audácia. Muito sério, devolve o caderno a BARTOLOMEU. 
INT. GABINETE - DIA

PADRE ALEXANDRE DE GUSMÃO, 51 anos, magro, cabelos grisalhos e expressões marcadas, está sentado em sua poltrona de leitura lendo um livro.

Atrás dele, uma estante de madeira, repleta de livros. Na sala também há um sofá com mesinha, uma grande escrivaninha e um quadro da primeira missa em Porto seguro.

PADRE ALEXANDRE pára de ler quando batem à porta.

PADRE ALEXANDRE

Pois não, entre.

BARTOLOMEU entra, meio ofegante, com seu caderno debaixo do braço.

\section{BARTOLOMEU}

Com a vossa licença, padre

Alexandre.

BARTOLOMEU se aproxima do PADRE ALEXANDRE abrindo o caderno.

\section{BARTOLOMEU}

Descobri um modo de trazer a água

do brejo para o colégio.

PADRE ALEXANDRE olha intrigado para ele.

A cela foi transformada no pequeno laboratório. Há várias plantas penduradas, pedras de diferentes tamanhos, formas e cores, metais separados em caixas, algumas invenções, muitos instrumentos, livros e um fogareiro sobre a mesa. 
PADRE ALEXANDRE olha BARTOLOMEU colocar no chão uma tigela grande, com água, e uma tigela menor, vazia, em cima de um dos cantos da mesa.

BARTOLOMEU encaixa uma das extremidades de um tubo fino na tigela inferior e chupa o ar na outra extremidade, fazendo a água subir pelo tubo e encher a tigela superior, até que a água se derrame sobre a mesa e caia no chão.

BARTOLOMEU, muito satisfeito, olha para o PADRE ALEXANDRE e aponta no seu caderno o desenho do brejo murado, com um cano trazendo a água para o colégio, enquanto fala rápido.

\section{BARTOLOMEU}

Construíremos um muro para represar a água. Cá em cima colocamos um mecanismo...

PADRE ALEXANDRE faz cara de que não entende. BARTOLOMEU

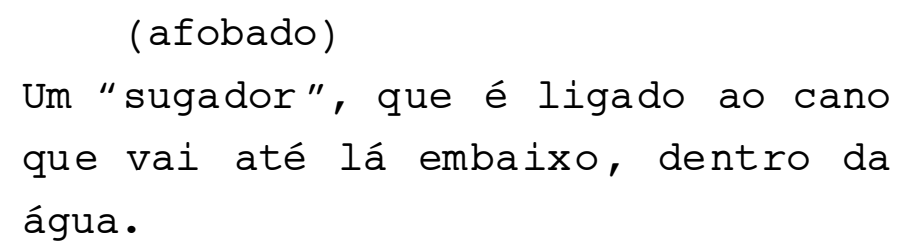

BARTOLOMEU respira quase sem fôlego e continua.

BARTOLOMEU

E aqui haverá um reservatório repleto!

O PADRE ALEXANDRE olha admirado para o caderno e para a água na tijela sobre a mesa. Segura o ombro de BARTOLOMEU, consentindo. 
PADRE ALEXANDRE

Quero só ver.

BARTOLOMEU

Terei de faltar a algumas aulas.

PADRE ALEXANDRE

Não me digas.

BARTOLOMEU apenas sorri.

EXT. BREJO - DIA

BARTOLOMEU, DIOGO e OS outros SEMINARISTAS quebram pedras e empilham-nas em volta do brejo.

MARIA chega com ALEXANDRE, 7 anos, irmão de BARTOLOMEU. Trazem frutas para os rapazes.

MARIA observa BARTOLOMEU comer, ele percebe, ficam se olhando. MARIA vai embora com a cesta repleta de cascas.

ALEXANDRE fica, quer ajudar, tenta quebrar uma pedra. BARTOLOMEU chega perto dele com um pedaço de pau comprido e grosso.

\section{BARTOLOMEU}

Não tens força ainda, meu irmão, a

pedra é muito dura. Mas podes

brincar com uma alavanca.

BARTOLOMEU mostra ao irmão como fazer uma alavanca com o pedaço de pau e uma pedra. ALEXANDRE consegue levantar uma pedra com a alavanca. 
Todos entram na lagoa, suados, nadam, brincam e se lavam.

ALEXANDRE tenta dar um caldo em BARTOLOMEU, que não deixa.

\section{BARTOLOMEU}

(alto)

Bem sabes que não gosto tanto assim

da água.

BARTOLOMEU vai até ele e o levanta no ar, gira com o garoto que grita.

\section{BARTOLOMEU}

$\mathrm{E}$ tu?

BARTOLOMEU joga ALEXANDRE com força, o garoto afunda na água.

11 INT. IGREJINHA DO SEMINÁRIO - NOITE

Entre os SEMINARISTAS, DIOGO, BARTOLOMEU e ALEXANDRE dormindo em seu ombro. Todos ouvem PADRE ALEXANDRE que está no púlpito. PADRE JOÃO olha feio para Bartolomeu.

PADRE ALEXANDRE

Além da vontade, é preciso oferecer

o entendimento... Ter o mesmo

querer, mas também o mesmo pensar do superior...

Diogo fala no ouvido de Bartolomeu.

DIOGO

(baixo)

Não deixes que durma, Padre João está a olhar-te feio... 


\section{BARTOLOMEU}

(baixo)

Tem sono, Diogo, e é criança. Não

tenho medo de superior.

DIOGO

(sorrindo disfarçado para

BARTOLOMEU )

Não tens medo de nada?

No fundo MARIA, sozinha, presta muita atenção no sermão.

PADRE ALEXANDRE

... olhai para aquele a quem no

homem obedeceis, para Cristo... o

Universo é a grande monarquia de

Jesus...

12 EXT. BREJO - DIA

BARTOLOMEU, DIOGO e OS SEMINARISTAS cercam a lagoa com as pedras, represando a água.

MARIA e ALEXANDRE assistem, sentados na grande pedra.

13 EXT. MORRO - DIA

MARIA pendura os panos no varal enquanto olha BARTOLOMEU, DIOGO e os SEMINARISTAS colocarem um enorme cano morro abaixo.

ALEXANDRE corre ao lado deles, pra cima e pra baixo.

14 EXT - SEMINÁRIO - DIA

PADRE ALEXANDRE, PADRE JOÃO, outros PADRES, ALEXANDRE, DIOGO e os SEMINARISTAS, ANTONIA e MARIA, que está muito feliz, observam de perto BARTOLOMEU destampar a ponta do cano, fazendo a água jorrar dentro de um reservatório no pátio do Colégio. 
ANTONIA

(emocionada)

Ai que esse menino é sabido demais!

ANTONIA e MARIA, que sorri largamente, se afastam e PADRE ALEXANDRE se aproxima, segura BARTOLOMEU firme nos ombros.

PADRE ALEXANDRE

Estou impressionado, senhor

Bertholameu Lourenço, realmente impressionado!

Todos fazem grande festa para BARTOLOMEU, menos o PADRE JOãO, que o cumprimenta friamente.

15 INT. GABINETE - NOITE

PADRE ALEXANDRE serve dois copos de vinho, entrega um a BARTOLOMEU e faz um brinde.

\section{PADRE ALEXANDRE}

Bem sabes que és o meu pupilo

predileto. Orgulho-me deveras de ti.

Eles bebem um gole lentamente. PADRE ALEXANDRE se senta no sofá, faz sinal para BARTOLOMEU que vem e senta-se ao seu lado.

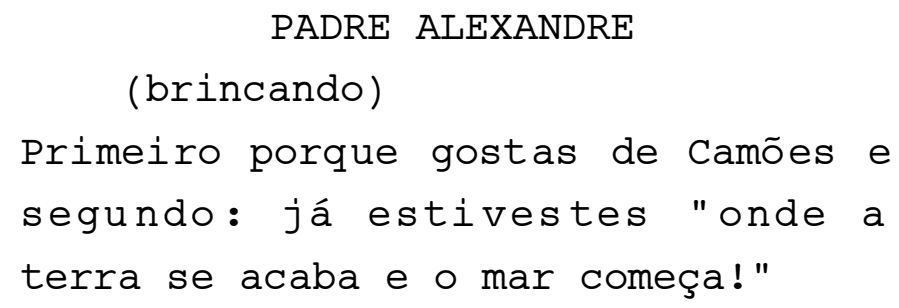

Eles se deleitam com outro gole, sentem o vinho passando na boca bem devagar, antes de engolir. 
BARTOLOMEU olha sério para o PADRE ALEXANDRE durante alguns segundos, cria coragem para falar.

\section{BARTOLOMEU}

Pois quando lá estive... não vos contei algo...

FADE IN :

Ao lado do elegante fidalgo MARQUÊS DE FONTES E ABRANTES e de seu filho ainda criança, O CONDE DE PENAGUIÃO, BARTOLOMEU olha para todos os lados.

Os olhos negros e brilhantes de BARTOLOMEU esquadrinham o luxo das cadeiras e dos ornamentos do grande salão do palácio real. Os ilustres convidados à sua volta são fidalgos, religiosos e membros da corte portuguesa.

O infante D. FRANCISCO, ainda menino, gordo e feioso, corre de um lado a outro do salão, rindo e se desviando das pessoas que, embora se incomodem, disfarçam.

o infante só pára quieto, ao lado do príncipe, o préadolescente rechonchudo que virá a ser o rei D. João V, quando D. NUNO entra acompanhando do REI e da RAINHA. Depois das reverências, o REI senta-se no trono. Todos a ouvi-lo.

REI

Parece que no Brasil não há só índios e escravos, nem de lá vêm apenas a gente da nação a ser julgada pelo santo oficio... (MORE) 


\section{REI (cont'd)}

Recebemos hoje, a mando da Companhia dos Jesuítas e anfitriado pelo Marquês de Fontes e Abrantes...

O REI Olha para O MARQUES que se curva, orgulhoso. Em seguida olha para BARTOLOMEU, que também se curva.

REI

... este jovem brasileiro,

Bertholameu Lourenço.

(para BARTOLOMEU)

Temos ouvido que tens uma memória

prodigiosa, que conheces as

Escrituras como ninguém.

(para todos)

Pois, gostaríamos de ver se isso é realmente verdade.

D. NUNO entrega O Velho Testamento ao REI que abre em uma página marcada e pergunta a BARTOLOMEU.

REI

A oitava eclesiaste?

BARTOLOMEU abaixa o corpo reverênciando o REI antes de responder.

\section{BARTOLOMEU}

"A obediência devida ao rei: Quem é tal como o sábio? E quem sabe a interpretação das coisas? A Sabedoria do homem alumia o seu rosto, e a aspereza do seu rosto se muda. Eu digo: Observa o mandamento do rei, porém segundo a palavra do juramento que fizeste a Deus." 
O REI que acompanhava a leitura no livro faz que sim com a cabeça.

REI

Pois não é isso mesmo!?

O REI sorri para BARTOLOMEU, que se curva e depois agradece com um aceno de cabeça. O REI devolve o livro a D. NUNO, que o segura sem abrir, semblante fechado, frio. Ele encara BARTOLOMEU durante alguns segundos.

D. NUNO

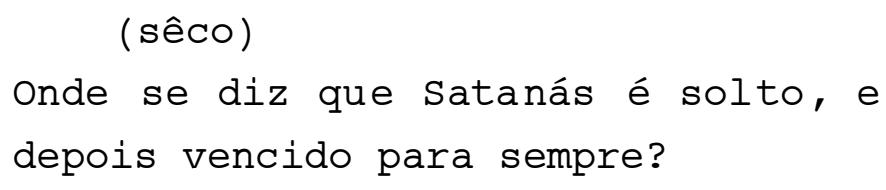

BARTOLOMEU está sério, estranhando o pedido, com medo de D. NUNO.

\section{BARTOLOMEU}

No Apocalipse de São João, senhor...

D. NUNO

Pois então, também o tens

decorado?

BARTOLOMEU vacila, olha em volta, demora a falar. Todos olham para ele.

\section{BARTOLOMEU}

"E acabando-se os mil anos, Satanás será solto de sua prisão. E sairá a enganar as nações que estão sobre os quatro cantos da terra, Gog e Magog, para os ajuntar em batalhas, cujo número é como a areia do mar." 
D. NUNO parece desafiar BARTOLOMEU.

\author{
D. NUNO \\ Quero o restante, de trás para \\ diante.
}

BARTOLOMEU engole em seco antes de continuar.

\title{
BARTOLOMEU
}

"Sempre o todo para atormentados serão noite de e dia de e; profeta falso o e besta a estão onde, enxofre e fogo do lago no lançado foi, enganava os que, diabo o e. Devorou os, e céu do fogo desceu Deus de e; amada cidade a e sanctos dos arraial o cercaram e, terra da largura sobre subiram e."

D.NUNO parece satisfeito, como se tivesse ganhado o jogo. 0 MARQUES observa O CONDE fascinado por BARTOLOMEU. BARTOLOMEU vê que D. NUNO, desconfiado, aproxima-se do REI, ouve o que ele fala.

\section{NUNO}

Majestade, todo o cuidado é pouco, esse gajo tem parte com o demônio.

FADE OUT.

PADRE ALEXANDRE e BARTOLOMEU continuam no sofá, a garrafa na mesinha já pela metade. 


\section{PADRE ALEXANDRE}

Não tens o que temer, meu filho, é apenas uma lenda. Dizem que falar assim, de trás para diante, é bruxaria...

\section{BARTOLOMEU}

E não é?!

\section{PADRE ALEXANDRE}

Mas claro que não! Bruxaria não existe. Você tem uma memória excepcional e é muito inteligente, só isso, ou melhor, tudo isso.

PADRE ALEXANDRE observa BARTOLOMEU, sorriem levemente, bebem em silêncio.

\section{PADRE ALEXANDRE}

Sentes um desconcerto?

\section{BARTOLOMEU}

$$
\text { (brincando) }
$$

"Tanto de meu estado me acho incerto"...

PADRE ALEXANDRE de repente ficou muito mais velho. BARTOLOMEU repara no relógio na escrivaninha, ouve o tic tac.

\section{BARTOLOMEU}

Mas às vezes sinto que uma hora tem mil anos.

\section{PADRE ALEXANDRE}

Pois mais me parece o oposto, Bertholameu, os anos é que passam como se fossem horas. 
PADRE ALEXANDRE olha para a frente em silêncio. BARTOLOMEU, que não consegue ficar parado por muito tempo, levanta-se e beija o anel de seu tutor.

\section{BARTOLOMEU}

Bênção.

PADRE ALEXANDRE sorri levemente e faz que sim com a cabeça.

18 INT - LABORATÓRIO DE BARTOLOMEU - NOITE

Além das velas, há um lampião aceso.

BARTOLOMEU acende o fogareiro e observa as chamas que se movem.

BARTOLOMEU abre um tubo de vidro e despeja o mercúrio em uma pequena bacia, sem querer, encosta sua mão no líquido espesso. Lava as mãos rapidamente e forma uma bolha de sabão enquanto se aproxima do fogo.

A bolha, aquecida, sobe até o teto lentamente, paira alguns segundos e desce devagar até bater na mesa e explodir.

Ouve-se o coração de BARTOLOMEU batendo alto e rápido.

Atônito, BARTOLOMEU faz outra bolha, maior, que também sobe sobre $\circ$ fogo.

Ele olha fascinado e imóvel para a bolha que paira no ar durante alguns segundos, enquanto o tempo parece parar.

19 EXT - JARDIM DO SEMINÁRIO - AMANHECER

BARTOLOMEU anda pelo jardim olhando pássaros que levantam vôo, voam e voltam a pousar à sua volta.

BARTOLOMEU estende os braços com pequenos pedaços de pão nas mãos, os pássaros pegam os pãezinhos no vôo. 


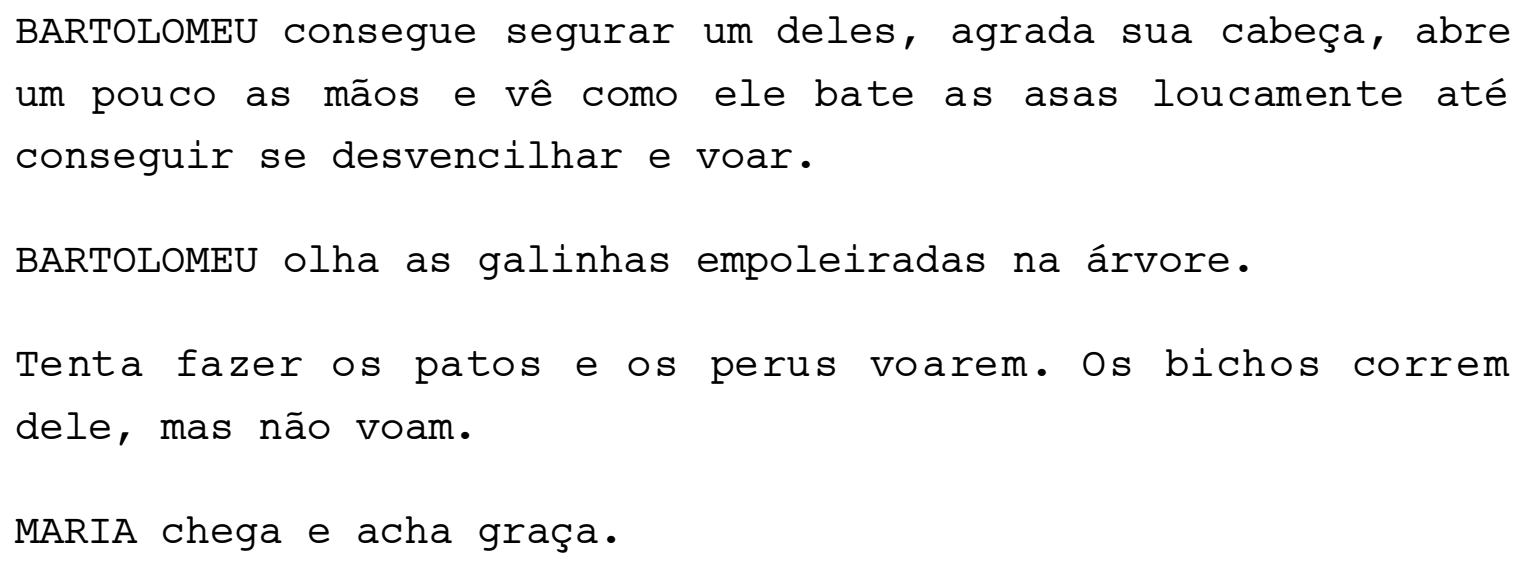

\section{BARTOLOMEU}

Uma vez escondi um ovo de ganso debaixo de minha cama. Vi nascer, alimentei. 
MARIA não parece acreditar no que ele diz.

\section{BARTOLOMEU}

Passou a vida atrás de mim, voava e voltava. Chamava-se Daniel, o nome de um profeta...

\section{MARIA}

Sabe o que a mãe disse? Que tu irás muito longe, onde ninguém nunca foi!

BARTOLOMEU se admira, MARIA sorri para ele e continua a jogar os milhos. BARTOLOMEU olha para as galinhas que pulam do galho da árvore.

\section{BARTOLOMEU}

Maria, podes dar-me os milhos?

MARIA

Queres para quê?

BARTOLOMEU

As galinhas querem.

MARIA entrega o resto dos milhos a BARTOLOMEU, que joga tudo para as galinhas.

MARIA

Vou colher umas ervas. A mãe precisa curar um doente.

BARTOLOMEU olha para MARIA entrando na mata atrás do terreiro. Ela pára e se volta para ele.

$$
\text { MARIA }
$$

Vais comigo? 
BARTOLOMEU

\section{Se quiseres...}

MARIA anda ao lado de BARTOLOMEU.

De repente, uma cobra coral grande passa perto deles. Os dois param e se grudam um no outro, apertando-se as mãos com força e em silêncio, vendo a cobra se afastar tranquiilamente.

BARTOLOMEU, deitado em sua cama à luz da vela, desenha um homem com asas em seu caderno.

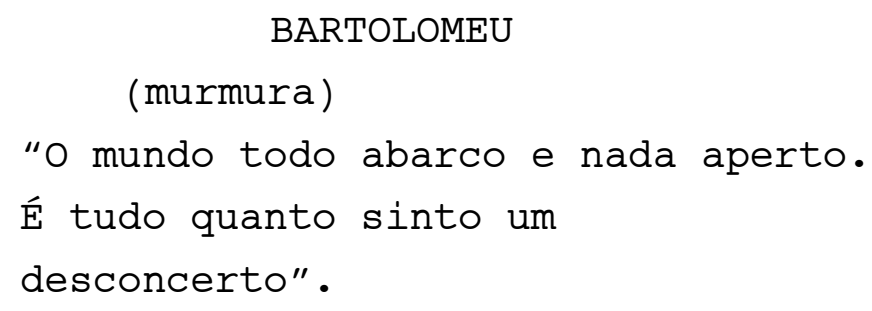

BARTOLOMEU olha para o castiçal com a vela e a ampulheta em cima do baú, a areia termina de cair, BARTOLOMEU vira a ampulheta, a areia começa a cair novamente.

21 EXT/INT - SENZALA - NOITE

BARTOLOMEU se aproxima da senzala, com o castiçal na mão, ouve batuques de atabaque e vozes que cantam em língua africana.

BARTOLOMEU entra pé ante pé, observa ANTONIA, fita larga amarrada na cabeça, dançando feito louca no meio da roda de negros que cantam e tocam os pequenos atabaques de modo repetitivo e sem parar.

De repente ANTONIA pára com os olhos fixos no teto. MARIA se aproxima de BARTOLOMEU, leva-o para fora. MARIA e BARTOLOMEU se afastam da senzala e entram no mato. 
MARIA

(baixinho)

Gostas mesmo do calundu!

Eles chegam numa pequena clareira e param. BARTOLOMEU ilumina o rosto de MARIA com a vela.

\section{BARTOLOMEU}

Gosto mesmo é de ti, Maria.

BARTOLOMEU se agacha e ilumina os pés descalços de MARIA, depois as canelas, as coxas, o ventre, os seios, o colo. BARTOLOMEU ilumina o pescoço dela, descobre suas orelhas, apalpa um dos ombros e estica seus braços.

\section{BARTOLOMEU}

Tens o nome mais bonito do mundo. o mesmo nome de minha mãe.

MARIA fica de braços abertos, como se fosse voar. Bate um vento que faz sua camisolona branca balançar.

\section{BARTOLOMEU}

E eres tão linda.

Eles se olham profundamente nos olhos.

\section{BARTOLOMEU}

São da cor do mar.

MARIA fecha os olhos, oferecendo a boca. BARTOLOMEU se aproxima devagar e encosta sua boca na dela. MARIA segura a cabeça dele e o beija levemente.

BARTOLOMEU e MARIA olham-se e se beijam com paixão. 
Gritos de pássaros na escuridão. O céu azul escuro torna-se roxo e vermelho.

Uma nuvem de pássaros voa baixo, sobre a praia, avançam no mar e somem no horizonte.

Pés descalços andam apressados sobre as pedras à beira do mar. São de BARTOLOMEU fugindo por entre as pedras até chegar na praia e correr pela areia.

BARTOLOMEU cai na areia, levanta-se, tenta sair do lugar, faz força para andar, mas não consegue. Ele olha para trás e vê ANTONIA, correndo ao seu encontro, histérica.

\section{ANTONIA}

(gritando)

Onde está Maria? O que fizeste com

a minha filha?! Maria!

Começa a ventar e BARTOLOMEU, finalmente, pode sair do lugar, ajudado pelo vento.

BARTOLOMEU corre desesperado pela praia, fugindo, perseguido por PADRE JOÃO, outros PADRES e SEMINARISTAS.

Quando está quase sendo alcançado por PADRE JOÃO, percebe que na verdade é D. NUNO quem o persegue.

Um vento muito forte ajuda a levar BARTOLOMEU, que bate os braços em desespero. De repente surge em cada braço uma asa de pano, esticada por varetas de madeira. Ele continua batendo os braços sem parar, começa a voar.

BARTOLOMEU olha para baixo e vê seus perseguidores na praia, vê as montanhas de cima. 
O mar azul escuro está bravo.

As ondas se formam com velocidade e batem com toda a força nas pedras enormes à beira da praia.

24 EXT - PRAIA DE SANTOS - DIA

BARTOLOMEU, 25 anos, de batina, caminha ao lado da MÃE, do PAI e de seus irmãos ALEXANDRE, 15 anos, JOÃO ALVARES SANTA MARIA, 8 anos, que está de mãos dadas com JOANA, 22 anos. Eles carregam um baú e duas maletas.

25 EXT. NAVIO/PORTO DE SANTOS - DIA

No porto movimentado, BARTOLOMEU, ALEXANDRE e a família param na frente do navio e o observam ser carregado de malas, caixas, baús. Atrás desse há outros navios sendo carregados.

Por último entram no navio os cristãos-novos, prisioneiros da Inquisição.

BARTOLOMEU repara na pouca bagagem da família de MIGUEL DE CASTRO LARA, 39 anos.

MIGUEL leva sua filha BRITES EUGENIA, 8 anos, pela mão. Atrás deles, o filho Jõ̃o TOMÁs, 11 anos, ao lado da mãe, sua esposa MARIA COUTINHO, 26 anos.

A cunhada LOURENÇA COUTINHO, 25 anos, seu marido JOÃO MENDES DA SILVA, 35 anos e o sobrinho ANTONIO JOSÉ, 12 anos, andam um pouco mais atrás. 


\section{BARTOLOMEU}

Donos de engenho, advogados, comerciantes... o confisco levalhes tudo!

\section{PAI}

Não deves meter-te nisso.

Constrangidos, todos desviam o olhar, menos BARTOLOMEU. JOANA o segura no ombro.

$$
\begin{aligned}
& \text { JOANA } \\
& \text { Que Deus os ilumine e os proteja. }
\end{aligned}
$$

BARTOLOMEU pega SANTA MARIA no colo.

BARTOLOMEU

Tens de estudar muito, ouviste?

BARTOLOMEU olha para a MÃE, que o beija na testa. ALEXANDRE beija a mão do PAI.

\section{PAI}

(para Bartolomeu)

Cuide como se fosse teu filho.

BARTOLOMEU

Claro meu pai, não tens com que

preocupar-te.

\section{$\mathrm{MÃE}$}

Escrevam-nos sempre.

BARTOLOMEU e ALEXANDRE pegam o baú e as maletas.

MAE

(emocionada)

Adeus! 
Ao lado do PAI, JOANA segura o braço da MÃE que dá a mão para SANTA MARIA. Eles observam BARTOLOMEU e ALEXANDRE embarcarem no navio.

BARTOLOMEU e ALEXANDRE acenam do navio para a família, que acena de volta.

26 EXT. NAVIO/MAR - DIA

BARTOLOMEU e ALEXANDRE observam a costa brasileira cada vez mais longe.

ALEXANDRE

Pobres desses que não podem crer no

que acreditam, não devem ser o que são.

\section{BARTOLOMEU}

Pois é preciso parecer, não ser.

Os dois ficam pensativos.

BARTOLOMEU

A Inquisição vive deles.

ALEXANDRE

E viste quantas caixas e baús os navios levam?

\section{BARTOLOMEU}

Tantas embarcações, todas

carregadas... Pois é a nossa

riqueza que sustenta o rei e a sua

corte, a Igreja, o Santo ofício e até a Inglaterra, meu irmão. 


\section{ALEXANDRE}

Não conseguirão acabar com tudo. O

Brasil é muito grande.

\section{BARTOLOMEU}

Assim seja.

27 EXT. NAVIO/OCEANO - NOITE

BARTOLOMEU observa as estrelas com um telescópio rudimentar, acrescenta um ponto no seu mapa celeste que ALEXANDRE ajuda a segurar, iluminado pelo lampião.

\section{BARTOLOMEU \\ (aponta no mapa e no céu) \\ o Cruzeiro do Sul, estás a ver?}

ALEXANDRE olha o mapa e depois o céu.

\section{ALEXANDRE}

o caminho de casa.

\section{BARTOLOMEU}

Serás um grande homem, Alexandre, quem sabe onde viverás...

\section{ALEXANDRE}

E tu com tua máquina, aonde irás?!

BARTOLOMEU sorri e não responde, olha para o céu pensativo. ALEXANDRE olha para o céu também. Eles vêem uma estrela bem brilhante.

\section{ALEXANDRE}

Como brilha!

\section{BARTOLOMEU}

Tu bem sabes que ela já não está lá há muito tempo. 
ALEXANDRE olha para BARTOLOMEU e sorri.

Os navios navegam perto um do outro.

o tempo muda deixando o céu escuro e o mar revolto.

O CAPITÃO e Os MARINHEIROS não conseguem dominar a nave que balança, debaixo da tempestade, entre as enormes ondas. Ouve-se o grito de senhoras e o choro de crianças no porão.

BARTOLOMEU sai do camarote e encontra ALEXANDRE assustado, ele segura o irmão com força, vão até o convés.

\section{BARTOLOMEU \\ Reze, meu irmão! \\ (olhando para o céu)}

BARTOLOMEU continua olhando firme para o céu, reza baixo, sem parar, coisas que não se entende.

ALEXANDRE olha para ele e para o céu, que clareia repentinamente.

BARTOLOMEU solta ALEXANDRE que está assombrado.

No porão alagado, BARTOLOMEU observa o penoso trabalho dos marinheiros no bombeamento da água.

Na proa, BARTOLOMEU, pensativo, observa os marinheiros e os cristãos-novos tirando a água do navio com baldes. Eles não dão conta.

BARTOLOMEU e ALEXANDRE ajudam MIGUEL e sua família a tirar a água do navio.

29 EXT - OCEANO - ENTARDECER

Na calmaria, o navio navega sozinho no oceano. 
Sobre o oceano sem fim, o céu.

A sala de jantar é espaçosa e iluminada. A mesa comprida está repleta de travessas de comida. BARTOLOMEU, mais magro e abatido, sentado do lado direito do MARQUêS DE FONTES E ABRANTES, sempre elegante e agora mais velho, na cabeceira. Do lado esquerdo do MARQUês está o seu filho, o CONDE DE PENAGUIão, que se tornou um jovem de traços delicados e expressão inteligente. ALEXANDRE come vorazmente ao lado de BARTOLOMEU.

\section{MARQUÊS}

Comeste pouco, Bertholameu.

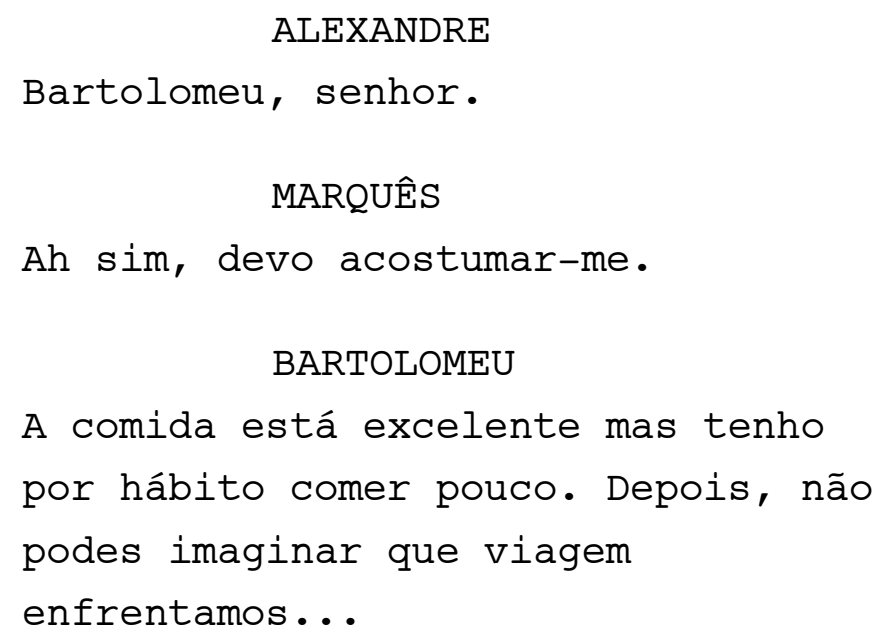

BARTOLOMEU suspira fundo. O MARQUÊS pega uma garrafa de vinho e mostra a BARTOLOMEU.

\section{MARQUÊS}

Teu irmão já bebe vinho? 
Um tantinho.

O MARQUÊS enche três copos, o de ALEXANDRE pela metade.

\title{
MARQUÊS
}

$\mathrm{E}$ que bons ventos o trouxeram a Portugal, Bartolomeu?

\section{BARTOLOMEU}

Além de meu irmão, uma petição ao Rei, o senhor pode se encarregar? Peço privilégio para o meu invento.

MARQUÊS

E O que inventaste afinal?

BARTOLOMEU

Uma máquina de voar.

O MARQUÊS sorri para ele, duvidando. O CONDE está muito sério, curioso. ALEXANDRE, orgulhoso, observa BARTOLOMEU beber o resto do vinho todo de uma vez.

\author{
MARQUÊS \\ Como assim voar? Inventaste asas? \\ BARTOLOMEU \\ (primeiro rindo, depois \\ sério) \\ Uma bolha de sabão. Sabias que \\ quando aquecida, a bolha voa? \\ MARQUÊS \\ Uma bolha é completamente diferente \\ de um homem!
}




\section{BARTOLOMEU \\ Claro, mas ela foi só o princípio \\ da descoberta...}

O MARQUÊS e O CONDE Olham BARTOLOMEU assombrados. ALEXANDRE acha graça.

31 EXT - PENHASCO- AMANHECER

o Tejo escuro ilumina-se ao sol vermelho que aparece no horizonte.

BARTOLOMEU, sentado em uma pedra à borda do penhasco, contempla os pássaros que cantam e voam.

O céu lilás se move, torna-se azul, um grande pássaro passa sobre a cabeça de BARTOLOMEU.

Á beira do rio surge uma mulher de longos cabelos pretos, é BRITES MARIA, 18 anos, que canta olhando para o horizonte.

BARTOLOMEU, encantado, observa-a tirar os sapatos, erguer o vestido e molhar os pés na água.

BRITES MARIA vê BARTOLOMEU, que fica sem-graça e se afasta.

32 INT - QUARTO DE BARTOLOMEU - DIA

BARTOLOMEU, ALEXANDRE e O CONDE tiram alguns instrumentos da maleta e os colocam sobre a mesa. No armário já estão os rolos de arame, os papéis, pedras, tubos e potes.

\section{BARTOLOMEU \\ (para o CONDE)}

Prometi ao nosso pai ensinar-lhe as línguas, as leis, a matemática, tudo o que sei. 


\author{
ALEXANDRE \\ (para $\bigcirc \mathrm{CONDE}$ ) \\ Depois vou estudar em Coimbra. \\ CONDE \\ (para ALEXANDRE) \\ Se fores igual ao teu irmão, é \\ certo, irás longe!
}

BARTOLOMEU e ALEXANDRE olham-se, cúmplices.

Na espaçosa sala de despachos, D. JOÃO V, D. NUNO DA CUNHA, FIDALGOS, O CONDE e SERVIÇAIS ouvem com atenção a petição que ○ MARQUÊS lê.

\title{
MARQUÊS
}

Diz o Licenceado Bartolomeu Lourenço, que ele tem descoberto um instrumento para andar pelo ar da mesma sorte que pela terra, e pelo mar, com muito mais brevidade...

D. NUNO impaciente não se contém.

D. NUNO

Um mameluco que não crê em Deus, nem em Jesus Cristo!

CONDE

Mas ele é padre, D. Nuno!

D. JoÃo olha para eles que se calam. D. NUNO cruza os braços. 


\section{MARQUÊS}

... Descobrir-se-ão as regiões mais vizinhas aos pólos do mundo, sendo da nação portuguesa a glória deste descobrimento.

Um dos outros fidalgos presentes mal segura o riso.

$$
\begin{array}{cc}
\text { CONDE } \\
\text { (para } \circ \text { Rei) }
\end{array}
$$

Estamos para realizar um grande sonho, Majestade...

$$
\text { D. JOÃO }
$$

Marquês, continue.

\section{MARQUÊS}

E porque deste invento se podem seguir muitas desordens, muitos crimes, o que se evita estando reduzido o uso a uma só pessoa...

\section{NUNO}

Ah, e só ele vai poder voar?!

CONDE

Ele inventou a máquina, não quer que qualquer um dela se apodere!

$$
\text { D. JOÃO }
$$

Deixem-me ouvir a petição até o final!

\section{MARQUÊS}

E proibindo-se a todas as mais sobre graves penas; e que bem se remunere ao suplicante invento de tanta importância... 
Todos olham para D. JOÃO que fica pensativo alguns segundos, antes de falar.

$$
\text { D. JOÃO }
$$

E quem vem a ser esse suplicante?

\section{MARQUÊS}

Talvez Vossa Majestade se lembre, há anos cá esteve comigo um jovem noviço que tinha de cor todos os livros.

D. JOÃO lembra-se bem dele.

$$
\text { D. JOÃO }
$$

Ah, não o digas!

D. NUNO se dá conta de quem é BARTOLOMEU, está de cara amarrada, não gosta nada do que ouviu.

TOMÁZ PINTO BRANDÃO, 45 anos, poeta, bebe com CATARINA SALEMA, 45 anos, cabelos presos e grisalhos.

Em uma mesa próxima BARTOLOMEU toma vinho sozinho. MIGUEL DE CASTRO LARA se aproxima dele.

MIGUEL

Com licença, Padre Bartolomeu...

Viemos no mesmo navio do Brasil.

BARTOLOMEU faz um gesto, convidando-o a sentar-se com ele.

\footnotetext{
BARTOLOMEU

Claro, lembro-me bem do senhor, de vossa família e da tempestade que passamos! Miguel, não é mesmo, tio de Antônio José?
} 
MIGUEL fica feliz por ter sido lembrado.

MIGUEL

Isso mesmo! Miguel de Castro Lara, do Rio de Janeiro. Estudei em Coimbra, sou advogado, trabalho com as leis, mas gosto muito de poesia...

\section{BARTOLOMEU}

"Agora espero, agora desconfio, agora desvario, agora acerto. Estando em terra, chego ao céu voando."

MIGUEL

Luís de Camões, inigualável!

BARTOLOMEU concorda com MIGUEL e lhe serve vinho, bebem. TOMAZ PINTO BRANDÃO, que presta atenção na conversa sorri malicioso.

Perto da janela, BARTOLOMEU declama baixo e faz gestos.

\section{BARTOLOMEU}

Já se levanta uma tormenta, que é o horror. Tolda-se o céu, enfurecemse os ventos, estremece a popa açoitada com a fúria das ondas; as velas vão em pedaços pelos ares... que gritos que desordens! 
o navio em que BARTOLOMEU viajou está debaixo da tormenta.

No convés, BARTOLOMEU segura ALEXANDRE, assustado.

BARTOLOMEU olha para MIGUEL que tenta cuidar da família assustada, BRITES chora, ANTONIO JOSÉ se segura em uma corda, olhos fixos em BARTOLOMEU.

BARTOLOMEU (V.O.)

o piloto perde o tino, o marinheiro não sabe onde acuda, e o miserável passageiro esmorecido, atônito, pálido e frio, vê a borda da nau submergida já, debaixo das ondas...

BARTOLOMEU fala enquanto acaba de escrever.

\section{BARTOLOMEU}

E o centro do abismo parece que

está por instantes, tragando-o.

Ao lado do caderno o rabisco de um mecanismo, o desenho de um barco em movimento, o rabisco de uma bomba com um parafuso de Arquimedes aspirando a água dos porões.

BARTOLOMEU olha para ALEXANDRE, dormindo na cama, livro aberto no colo. BARTOLOMEU pega o livro e o coloca sobre outros, em várias línguas, que estão no baú. Apaga sua vela. 
A areia da ampulheta termina de cair e o vidro estoura, aquecido por uma grande fogueira no meio da praça. Aos poucos, distinguem-se dentro dela pessoas queimando.

Escondido, BARTOLOMEU vê D. NUNO, MATEUS e OUTROS INQUISIDORES ao redor da fogueira.

BARTOLOMEU se afasta e eles o perseguem. BARTOLOMEU corre pela praça, bate os braços desesperadamente até começar a voar.

BARTOLOMEU vê D. NUNO e a fogueira, cada vez menores abaixo dele.

39 INT - IGREJA - DIA

BARTOLOMEU prega na pequena igreja para poucos fiéis atentos: na frente estão quatro freiras. A bela loira é TRIGUEIRINHA, 20 anos. As outras são PAULA, 18 anos, cabelos castanhos, magra, vidrada em BARTOLOMEU, e suas irmãs BÁRBARA, 22 anos e ANTÔNIA, 25 anos.

BARTOLOMEU
Dificultosa e admirável resolução a
que impele ao exílio! Quem há que
vendo o sol voltar todos os anos, à
mesma casa de onde saiu, e vendo-se
fora da sua o não combatam as
saudades da pátria!

No meio da Igreja está ALEXANDRE entre alguns ESTUDANTES brasileiros. 
No fundo, emocionado, MIGUEL, BRITES EUGENIA, JOÃO TOMÁS, MARIA COUTINHO, LOURENÇA COUTINHO, JOÃO MENDES DA SILVA, ANTONIO JOSÉ, todos muito atentos às palavras de BARTOLOMEU.

BARTOLOMEU
o coração aperta e se angustia, os
olhos apenas retêm as lágrimas: a
memória nos aflige sem cessar; o
sítio da pátria, as conversações,
os amigos, as saídas, os
divertimentos, tudo nos anda diante
dos olhos, tudo nos martiriza!

Todos ouvem e se comovem com o sermão.

BARTOLOMEU
Por que hei de viver tantos anos
desterrado? Que peito há, tão de
bronze que não arrebente de dor?

No final da missa, MIGUEL com olhos vermelhos, recebe a hóstia de BARTOLOMEU.

Atrás dele, MARIA COUTINHO também recebe a hóstia, mas antes de sentar-se novamente, retira-a rapidamente da boca e a coloca no bolso.

40 INT - SALA DO PAÇO - DIA

D. NUNO e D. JOÃo estão a sós, de portas fechadas na sala de despachos.

D. NUNO

Onde já se viu tamanho sacrilégio!

Ir ao céu? Chegar à casa de Deus?

(MORE) 
D. NUNO (cont'd)

Este padre é um feiticeiro e seu invento é uma heresia, uma afronta ao nosso santo ofício e à coroa portuguesa!

D. JOÃO, pensativo, olha para D. NUNO.

Ficam em silêncio.

41 INT - QUARTO DE BARTOLOMEU - NOITE

BARTOLOMEU e o CONDE estão trançando os arames sobre a mesa. ALEXANDRE, sentado na cama, pára de ler seu livro e fica atento ao irmão.

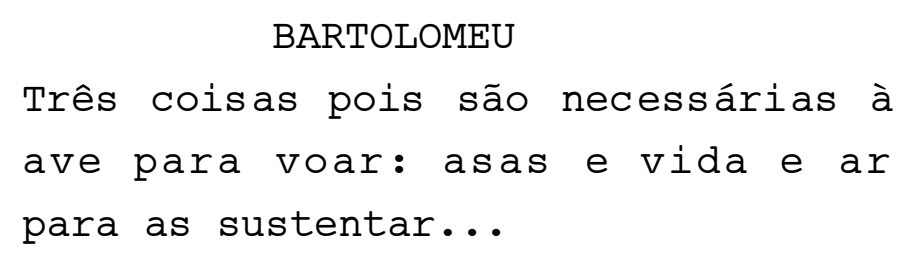

\section{BARTOLOMEU}

Diremos a eles que a naveta tem asas, tem ar e tem vida... Asas porque lhe formaremos à mesma imitação e proporção das aves...

ALEXANDRE se aproxima da mesa.

\section{BARTOLOMEU}

Terá ar porque este se acha em toda parte e terá vida nas pessoas, que o hão de animar o movimento...

o pequeno globo de arame fica pronto. 
BARTOLOMEU caminha na beira do rio, olha para cima e vê um grande pássaro preto no céu.

BARTOLOMEU continua a caminhar e é surpreendido por um vento muito forte, que levanta a areia, machucando-lhe o rosto e as mãos •

Som de trovões, luzes dos raios no céu, BARTOLOMEU se apressa.

43 EXT. CASEBRE - DIA

BARTOLOMEU anda debaixo de uma tempestade quando vê BRITES MARIA tecendo um cesto de palha na varandinha do casebre, que fica perto do rio.

BRITES MARIA vê o PADRE e grita para ele.

\section{BRITES MARIA}

Padre! Venha! Entre! Espere aqui até que passe a tempestade!

BARTOLOMEU aproxima-se todo molhado. BRITES sai e ele vê a palha e o cesto sobre a cadeira. Ela volta com um pano e oferece a ele.

\section{BRITES MARIA}

Seque-se.

BARTOLOMEU se seca.

BARTOLOMEU

Obrigada. Desculpe importunar tão cedo... 


\section{BRITES MARIA}

Não me incomodas. Por favor, cheguese. Vamos entrar.

BARTOLOMEU, um pouco tímido, entra atrás dela.

44 INT - CASEBRE - DIA

Sobre a mesa está a balança que CATARINA pegou na fogueira. Em um dos pratos algumas ervas, no outro algumas pedras.

BRITES MARIA Olha O PADRE BARTOLOMEU, que toma uma xícara de chá. Vê que ele repara na balança, mas nada dizem.

BRITES MARIA lhe oferece um pedaço de pão em uma cesta de palha.

BARTOLOMEU agradece com um gesto de cabeça, come devagar.

Ele olha primeiro para a cesta e depois para as mãos dela, enquanto fala.

\section{BARTOLOMEU}

A senhora fez este também?

BRITES MARIA

Sim.

BARTOLOMEU

Sem dúvida que eres uma artista!

BRITES MARIA sorri levemente para BARTOLOMEU.

45 INT - SALA DO PAÇO - DIA

D. FRANCISCO entra sem bater, D. JOÃo está só. 


\section{FRANCISCO \\ Preciso falar-lhe, irmão!}

D. FRANCISCO se aproxima de D. JOÃO.

D. FRANCISCO

(baixo)

Lembra-se de Trigueirinha?

D. Jõ̃o, desconfiado, pensa um pouco enquanto olha para o irmão.

\section{JOÃO}

Como hei de esquecer tal formosura?!

D. FRANCISCO

Pois quer muito vê-lo.

D. FRANCISCO, ar safado, ri e sai.

D. JOÃO faz sinal para um SERVIÇAL, que se aproxima.

\section{JOÃO}

Quero que mandes chamar o tal padre brasileiro.

46 INT - CONVENTO - DIA

TRIGUEIRINHA, beleza de traços delicados, está sentada dentro de uma grande tina, como se fosse uma rainha. PAULA joga um pouco de água em seus longos cabelos loiros.

BÁRBARA entra e pega $\circ$ balde das mãos da irmã.

\section{BÁRBARA}

A madre quer falar-lhe. Podes deixar que continuo. 
Quando PAULA sai, BÁRBARA começa a lavar os cabelos da TRIGUEIRINHA.

\section{BÁRBARA}

Ele virá ver-te, tens que estar muito bela e formosa....

BÁRBARA passa o sabão na nuca de TRIGUEIRINHA, que vai se virando de frente, fazendo BÁRBARA passar o sabão em seu pescoço, colo e braços. TRIGUEIRINHA se vira novamente e BÁRBARA se ajoelha, passando o sabão em suas pernas e pés.

\section{TRIGUEIRINHA}

\section{Ai, fazes cócegas!}

BÁRBARA enche o balde de água e a despeja na TRIGUEIRINHA, que sai da tina. BÁRBARA coloca a toalha em volta do seu corpo e a abraça.

BARTOLOMEU sentado à frente de D. JOÃO, sobre a mesa alguns desenhos.

\section{BARTOLOMEU}

Dão todos crédito à navegação dos mares só porque os vemos sulcados continuamente, que se tal não se via é certo que não se crera por ser invento tão dificultoso, que até salomão depois de ver o admirou...

BARTOLOMEU levanta-se e anda de um lado para outro. 


\section{BARTOLOMEU}

Além de demarcar todas as terras do Vosso reino, irá conhecer as verdadeiras longitudes, tornar os mapas mais precisos e até diminuir os naufrágios.

BARTOLOMEU volta a sentar-se, mostra o desenho da nova invenção para tirar a água dos navios.

\section{BARTOLOMEU}

Aproveito para mostrar-lhe outro invento: aqui temos vários modos de esgotar sem gente as naus que fazem água.

$$
\text { D. JOÃO }
$$

Ah, verdade?

\section{BARTOLOMEU}

Sim, Majestade. Está claro que esta é uma dificuldade comum a todos os povos...

O REI concorda com a cabeça.

\section{BARTOLOMEU}

... mais própria porém da nação portuguesa, cujas terras estão em todas as partes e as embarcações se espalham por todos os oceanos.

D.JOÃO observa o desenho e sorri para BARTOLOMEU, admirado.

Um SENHOR geme deitado na esteira. 
CATARINA SALEMA, cabelos soltos e compridos, pega as ervas de cima da balança. Embora as pedras estejam no outro prato, a balança não se mexe.

CATARINA pica as várias ervas com as mãos e joga-as numa panela borbulhante sobre o fogo, aproxima-se do senhor e apalpa seu estômago. O SENHOR começa a chorar baixinho.

CATARINA pega um pouco do líquido da panela e verte em uma caneca. Enquanto assopra, fala frases incompreensíveis. o senhor a olha com confiança. Ela o ajuda a beber, ele silencia e adormece.

CATARINA passa um ungüento no estômago do SENHOR, faz uma massagem. Em seguida, senta-se em uma das cadeiras.

BRITES MARIA chega e olha o SENHOR dormindo.

\section{BRITES MARIA}

Ele está melhor?

CATARINA

Agora sim.

49 INT - SALA DO MARQUÊS - DIA

$\grave{A}$ mesa repleta de travessas, BARTOLOMEU, O MARQUÊS, O CONDE e ALEXANDRE almoçam.

BARTOLOMEU

Importa é que D. João se mostra interessado!

CONDE

Mas D. Nuno da Cunha fará de tudo para impedir-te. 


\section{BARTOLOMEU}

Preocupa-me muito mais guardar em segredo o funcionamento da máquina.

MARQUÊS

Todos discutem isso na corte e nas ruas.

\section{BARTOLOMEU}

Preciso equivocá-los.

\section{ALEXANDRE}

Tens medo que lhe roubem a idéia?

BARTOLOMEU, sério, anui com a cabeça. Em seguida, não aceita o porco que lhe oferecem.

\section{BARTOLOMEU}

Não. Obrigado. Já estou mais do que satisfeito.

ALEXANDRE come um pedaço do porco, meio ressabiado.

50 INT- QUARTO DE BARTOLOMEU - DIA

BARTOLOMEU mostra a ALEXANDRE e ao CONDE, admirados, o desenho da Passarola.

\section{BARTOLOMEU}

Uma naveta, que voa como um pássaro...

CONDE

Está muito bom!

BARTOLOMEU

Precisamos anotar as explicações. Servirão para enganar os curiosos. 
O CONDE senta-se no canto da mesa e anota, enquanto ALEXANDRE observa BARTOLOMEU colocar as letras no desenho.

\section{BARTOLOMEU}

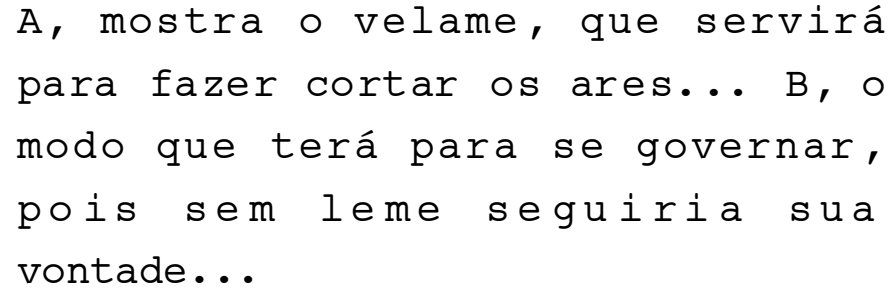

51 EXT/INT - CONVENTO - NOITE

D. JOÃo chega ao convento e é levado por BÁRBARA ao enorme quarto que parece um ninho de fada. TRIGUEIRINHA o espera.

\section{TRIGUEIRINHA}

Meu adorado Rei! Há quanto tempo

não vens me visitar...

$$
\text { D . JOÃO }
$$

Ando muito ocupado.

MARIA COUTINHO, de banho tomado e roupas limpas, coloca uma toalha branca, limpa, sobre a mesa. Em seguida, vai até o armário e abre as portas; dentro, sobre a prateleira, um castiçal com velas. MARIA COUTINHO acende as velas e estende as mãos sobre elas. 
MARIA COUTINHO

(murmura)

Bendito sejas, ó Eterno, nosso

Deus, Rei do Universo, que nos

santificaste por teus mandamentos e

nos ordenaste acender as velas do

shabbat.

53

INT - CASA DE MIGUEL - NOITE

MIGUEL ronda a mesa posta.

JOÃO TOMAS

Cheiro bom!

LOURENÇA COUTINHO, JOÃO MENDES e ANTONIO JOSÉ chegam. LOURENÇA segura um pão trançado que entrega a MARIA.

LOURENÇA

Trouxe o pão, irmã.

BARTOLOMEU bate à porta. BRITES EUGENIA abre e beija a mão de BARTOLOMEU, que a retira rapidamente, tímido.

MIGUEL
Bem-vindo à nossa casa! Uma honra
ter aceitado o convite.

BARTOLOMEU cumprimenta a família toda.

BARTOLOMEU

Imagine... Boa noite a todos.

MIGUEL o acompanha até a mesa. Todos se sentam à mesa.

MIGUEL

Já lhe disse que gostei muito

daquele vosso sermão?

(MORE) 
MIGUEL (cont'd)

Todos sentimos tantas saudades do Brasil...

MARIA COUTINHO

Miguel não tem falado de outra coisa!

JOÃO TOMAS

Lê para ele, pai.

MIGUEL

Desculpe-me pelo atrevimento, mas vossas belas palavras inspiraram-me a escrever um soneto, singelo, mas do fundo do coração...

MIGUEL tira do bolso um papel e lê para BARTOLOMEU.

MIGUEL

No matrimônio o vínculo sagrado/ causa no esposo o jugo conhecido:/ mas vós fazeis jugo apetecido, trocando a doce escravidão em doce agrado.

\section{BARTOLOMEU \\ Orgulha-me tê-lo inspirado. (para MARIA COUTINHO)}

$\mathrm{E}$ que bela declaração à senhora. LOURENÇA

Nosso filho Antonio José também gosta muito de escrever.

BARTOLOMEU olha para ANTONIO JOSÉ.

BARTOLOMEU

Eu sei, conversamos no navio...

(para ANTÔNIO JOSÉ)

(MORE) 
BARTOLOMEU (cont'd)

Tens de ler muito para escrever

bem.

ANTONIO JOSÉ sorri e faz que sim com a cabeça.

MARIA COUTINHO senta-se à mesa e serve os pratos da sopa na tijela.

MARIA COUTINHO

Espero que o senhor goste, é uma receita de família.

BARTOLOMEU vê o bolinho de matzá no fundo de seu prato. Todos olham para ele, esperando que beba a sopa. BARTOLOMEU percebe, coloca a colher na beirada do prato e experimenta.

BARTOLOMEU

Humm, que belo caldo, senhora.

MIGUEL parte o pão trançado e dá o primeiro pedaço para BARTOLOMEU, a seguir abre o vinho, coloca nos copos e faz um brinde.

MIGUEL

Ao nosso convidado!

Todos bebem olhando para BARTOLOMEU.

BARTOLOMEU

A nossa amizade.

54 INT - CONVENTO - NOITE

TRIGUEIRINHA, fogosa, deitada na cama.

D. JOÃO a contempla alguns segundos antes de colocar várias moedas de ouro sobre o seu corpo, debaixo do lençol transparente. 


\section{Estás linda!}

$$
\text { D. JOÃO }
$$

Todos já se foram. MIGUEL e BARTOLOMEU ainda bebem vinho enquanto conversam perto do fogo, BARTOLOMEU está meio alto.

\section{BARTOLOMEU}

Está claro que Jesus era judeu, assim como todos os seus apóstolos.

\section{MIGUEL}

Para nós há três cousas difíceis de entender... A virgindade de Nossa Senhora, o Espírito santo e a ressurreição de Cristo.

\section{BARTOLOMEU}

São fenômenos sem explicação, sabemos disso.

(pausa)

Sabes que em Santos pude aprender como os índios veneram a natureza, vivem dela e por ela.

MIGUEL fica curioso.

MIGUEL

Não me digas...

\section{BARTOLOMEU}

Depois cheguei a conhecer um tantinho a religião africana, lá na Bahia.

(pausa)

E também já estudei o Alcorão. 
MIGUEL se assusta.

MIGUEL

Oh, é mesmo?

BARTOLOMEU

Todos têm um Deus. Parece diferente mas eu creio ser o mesmo Deus.

MIGUEL

(pensativo)

Pode ser... Mas e os santos, o que pensas dos santos?

BARTOLOMEU

O problema da Igreja está em sua rigidez, não há liberdade para o pensamento, nem para a descoberta. Não agüentei o seminário. Fui-me antes.

MIGUEL

Mas tornou-se religioso.

BARTOLOMEU

Aprendi muito com os jesuítas, com as leituras do Padre Antonio Vieira, porém, às vezes, tenho dúvidas.

MIGUEL

Pois todos temos. 
Luzes de velas iluminam os negros sentados na penúmbra. Ouvese os batuques de atabaque e as vozes que cantam em língua africana e em português.

BARTOLOMEU dança feito louco no meio da roda de negros que cantam e tocam os pequenos atabaques de modo repetitivo e sem parar. ANTONIA e MARIA também tocam e cantam.

De repente BARTOLOMEU pára com os olhos fixos no teto.

O telhado se abre e uma enorme bolha de sabão desce no meio da senzala.

MARIA, grávida, já pendurada na bolha dá a mão para BARTOLOMEU, que sobe com ela, levados pela bolha.

A senzala pega fogo.

57 INT - CONVENTO - AMANHECER

TRIGUEIRINHA puxa a mão de BáRBARA por um corredor, elas andam cada vez mais rápido, até entrarem em uma salinha com um oratório.

\section{BARBARA}

Mas o que tiveste de fazer?

TRIGUEIRINHA faz mistério, mostra as moedas que ganhou do REI.

\section{TRIGUEIRINHA}

Interessa o que ganhamos...

BÁRBARA pega-as das mãos dela e conta quantas tem. 
D.JOÃO, a RAINHA, D.NUNO e FIDALGOS reunidos.

BARTOLOMEU, ALEXANDRE, O CONDE e O MARQUÊS se aproximam.

\section{BARTOLOMEU}

Vossa Majestade me permita, apresentar-vos meu irmão Alexandre de Gusmão.

$$
\text { D. JOÃO }
$$

Ah, e também serás padre?

\section{ALEXANDRE}

Não, senhor, interesso-me mais pelas leis dos homens, aquelas que nós mesmos podemos criar, ou modificar quando necessário.

D. JOÃO sorri, gosta de ALEXANDRE, faz sinal para que se acomode próximo a ele.

$$
\text { D. JOÃO }
$$

\section{(para BARTOLOMEU)}

Estamos prontos para ver teu invento!

BARTOLOMEU coloca fogo na vela debaixo do pequeno globo, que pega fogo sem subir.

Burburinho no salão, alguns riem, outros comentam entre si. ALEXANDRE, O MARQUÊS e O CONDE ficam sem jeito enquanto D. NUNO triunfa.

BARTOLOMEU se aproxima de D.JOÃO. 


\section{BARTOLOMEU}

Perdoe-me Majestade. O fogo da vela estava muito forte. Imploro que me deixe fazer outra demonstração.

59 INT - TRIBUNAL - DIA

MASMORRA :

Penúmbra, vários instrumentos de tortura espalhados.

D. NUNO observa friamente MATEUS e outro INQUISIDOR torturando um homem, que desmaia.

D. NUNO

Deixem-no agora. Precisa recuperar-

se para falar, já está quase

morto!... Mateus, venha comigo.

CORREDOR :

D. NUNO e MATEUS saem da masmorra e caminham por um longo corredor escuro, em silêncio.

Ouve-se gemidos e gritos atrás das portas fechadas.

SALA DE AUDIÊNCIA:

D. NUNO e MATEUS entram na sala espaçosa.

D. NUNO senta-se à frente da enorme escrivaninha preta e aponta alguns processos que estão sobre ela.

D. NUNO

Há algum novo denunciado?

MATEUS

Novo não. Mas dois que podem vos interessar... 
MATEUS folheia os processos e puxa um deles para cima dos outros.

MATEUS

Maria Coutinho delatada mais duas vezes.

D. NUNO folheia o processo.

$$
\text { D. NUNO }
$$

Todos os cristãos-novos seguem sempre a judaizar. Então?

\section{MATEUS}

O marido também foi delatado. Não sei se valem a pena, já perderam tudo quando vieram do Brasil, mas são conhecidos do padre brasileiro.

D. NUNO

Pois agora tens que conseguir uma delação contra ele.

60 INT - CASA DE MIGUEL - DIA

Com a cabeça coberta MIGUEL reza baixo.

MIGUEL

Deus de Abraão, Deus de Isac, Deus de Jacob, Deus de Israel, Senhor Adonai, criador imenso do céu e da Terra...

JOÃO TOMÁS, JOÃO MENDES e ANTONIO JOSÉ também estão de cabeça coberta. Do outro lado da sala BRITES EUGENIA, LOURENÇA e MARIA COUTINHO.

Todos rezam em silêncio com MIGUEL, compenetrados. 
MIGUEL

Vós que criastes em seis dias todas as maravilhas do mundo, louvado sejais de todos os anjos, e de todas as criaturas, tende misericórdia de nós, favorecei-nos, e amparai-nos e livrai-nos assim como livrastes a judia, a Ester, e ao vosso Povo.

PAULA afasta-se de TRIGUEIRINHA e de suas irmãs ANTÔNIA e BÁRBARA, que vão em direção da porta enquanto ela se dirige ao confessionário.

BARTOLOMEU sente a respiração de PAULA, que chora com a cabeça encostada no confessionário.

Atrás deles, em um altar, sambenitos de diferentes épocas pendurados, neles os rostos de condenados à morte estampados entre o fogo revolto, de cabeça para baixo, os nomes inscritos.

PAULA

Não queria, padre. Mas sinto meu coração bater com muita força, minhas mãos suam tanto e parece que vou cair, desmaiar, morrer.

\section{BARTOLOMEU}

Calma, irmã. Todos passamos por provações. Tens que ser forte, teu amor por Deus é muito maior.

PAULA

Não me parece. 
PAULA olha para dentro do confessionário e consegue ver os olhos de BARTOLOMEU. Em seguida, afasta-se e vai embora correndo.

BARTOLOMEU sai do confessionário contrariado quando um funcionário da Inquisição está terminando de fixar um Édito da Graça perto da porta.

BARTOLOMEU caminha devagar até a porta. Lê no documento os nomes de Maria Coutinho e Miguel de Castro Lara: têm o tempo da graça de trinta dias para se apresentarem ao Santo ofício, confessarem suas culpas e serem absolvidos de seus pecados e reconciliados.

62 EXT. BARCO NA RIBEIRA - DIA

Tiros na barca.

HOMEM leva um tiro e cai na água. Outro se joga da barca e sai nadando, desesperado.

63 INT/EXT - SALA DO PAÇO - DIA

D. FRANCISCO, de uma das janelas, atira a esmo nas embarcações ancoradas na ribeira e gargalha.

D. JOÃo entra na sala de despacho com D. NUNO e alguns fidalgos.

D. NUNO

O que estais a fazer, D.Francisco?!

Dê-me cá esta arma!

D. FRANCISCO obedece a D. NUNO. 
D. NUNO

Não deveis mais fazer isso, já vos disse! Vá já para os seus aposentos e pensai no que estavas a fazer...

Os fidalgos saem com D. FRANCISCO.

D. NUNO e D. JOÃO sentam-se.

D. NUNO

Não podemos deixá-lo só...

D. JoÃo, desanimado, faz que sim com a cabeça.

D. NUNO

Vim para falar-vos mais uma vez sobre o tal brasileiro que se diz padre. Soube que é amigo de cristãos-novos. Não deveis apoiar o sacrilégio. Muito menos sustentá10 !

D. JOÃO

D. Nuno, há tempos não temos um atode-fé.

D. NUNO

Tendes saudades do cheiro de carne queimada, não é?!

D. JOÃO

Não me digas uma coisa dessas!

Os dois riem. 
BRITES MARIA e CATARINA saem pelos fundos do quintal com uma sacola.

BRITES MARIA canta enquanto as duas catam ervas na mata.

\section{CATARINA}

Venha ver! Uma mandrágora!

As duas observam, maravilhadas, a mandrágora.

65 INT - TRIBUNAL - DIA

MATEUS entrega o desenho da passarola para D. NUNO.

$$
\text { MATEUS }
$$

Aqui está.

D. NUNO, incrédulo, estica-o sobre a mesa.

$$
\text { D. NUNO }
$$

Então é isto?

D. NUNO observa o desenho nos mínimos detalhes.

\section{MATEUS}

Tal qual desenhou. Deu-lhe a alcunha de passarola.

$$
\text { D. NUNO }
$$

Tem a face de um diabo, este pássaro! E essas figuras esféricas?

(lendo)

Em que está seguro o atrativo...

D. NUNO Olha para MATEUS. 
D. NUNO

E aqui diz que atrairá a si continuamente a barca... Mas como?... Isso é feitiçaria! Não lhe parece, Mateus?

MATEUS

Seguramente, D. Nuno. Já temos uma delação que esteve a ceiar na casa de Castro Lara. Numa sexta-feira.

D. NUNO

(satisfeito)

Muito bom.

CATARINA bebe sozinha quando PINTO BRANDÃO entra e senta ao seu lado. Ela lhe oferece um gole, ele aceita e pede outra garrafa.

$$
\text { PINTO BRANDÃO }
$$

Achei que só a senhora soubesse voar...

\section{CATARINA}

De passarola parece que qualquer um poderá!

$$
\text { PINTO BRANDÃO }
$$

Não, senhora! Só quem for amigo do rei.

\section{CATARINA}

Ou do padre.

Eles riem alto. 
BRITES MARIA chega e segura a mãe, fazendo-a levantar.

$$
\text { PINTO BRANDÃO }
$$

Mas por que a senhora não senta?

Fique com vossa mãe aqui.

BRITES MARIA não responde, leva a mãe embora.

$67 \quad$ EXT - RUA - NOITE

CATARINA, ligeiramente trôpega, é ajudada por BRITES MARIA, as duas caminham devagar.

Vêem inquisidores tirando família de dentro de uma casa, lacrando a porta e levando-a com eles.

Família é jogada no chão da masmorra, ao seu lado MARIA COUTINHO, machucada, dorme.

69 INT - CASA DE JOÃO MENDES DA SILVA - DIA

BARTOLOMEU e JOÃO MENDES estão sentados à mesa em silêncio. ANTONIO JOSÉ os observa do canto.

BARTOLOMEU levanta e anda de um lado para outro.

\section{BARTOLOMEU}

Posso tentar, mas duvido... D. Nuno

me odeia e D. João não ordena nada

no santo ofício...

\section{JOÃO MENDES}

Não conhecemos mais ninguém a quem apelar... 
D. JOÃO, a RAINHA, D.NUNO e FIDALGOS reunidos. BARTOLOMEU coloca fogo no líquido sob o globo, que sobe até o teto, fica lá alguns segundos.

Todos olham assombrados o globo pairando no ar e depois a sua lenta queda, ardendo em fogo. Junto com ele queima uma cortina.

Grande alvoroço na sala. D.JOÃO sorri para BARTOLOMEU, O CONDE corre para ajudar ALEXANDRE a apagar o fogo. O MARQUÊS, eufórico, cumprimenta BARTOLOMEU.

BARTOLOMEU repara como D. NUNO se isola, cara fechada.

PASSAGEM DE TEMPO

A sós, D. Jõ̃o termina o seu cálice de vinho do Porto e BARTOLOMEU mal bebeu do seu.

$$
\text { D. JOÃO }
$$

Bem, de agora em diante serás o nosso capelão. Quero que rezes hoje mesmo na capela do reino.

\section{BARTOLOMEU}

Será uma grande honra, majestade.

BARTOLOMEU está incomodado, D. JOÃO percebe.

\section{JOÃO}

O que te afliges? Sabes que não deixo faltar nada a tua família. Teu pai seguirá recebendo a mesma quantia até minha morte. 


\section{BARTOLOMEU}

Agradeço muito vossa enorme generosidade. Estou aflito por outra questão.

BARTOLOMEU silencia, olha para baixo. Toma coragem e continua.

\section{BARTOLOMEU}

Atrevo-me a pedir a Vossa Majestade que intercedeis a favor de brasileiros amigos, cristãosnovos...

D. JOÃO

Ora Bartolomeu, bem sabes que não posso me indispor com D. NUNO. Não deverias andar com essa gente da nação.

BARTOLOMEU suspira fundo. D. JÕ̃O fica pensativo alguns segundos.

$$
\text { D. JOÃO }
$$

Aconselho-te mesmo a escrever um sermão, dedicando-o a D. NUNO. Ele será o novo Cardeal.

BARTOLOMEU parece apreensivo com a notícia.

71 INT - TRIBUNAL - NOITE

D. NUNO sentado junto a grande mesa à frente de MIGUEL. Na outra mesa, escrivão anota tudo. 
D. NUNO

A família de sua senhora vem sendo penitenciada há praticamente dois séculos!

D. NUNO folheia o processo que está sobre a mesa.

D. NUNO
o senhor, tendo-a escolhido como
esposa, deve compartilhar das
mesmas práticas judaizantes.

MIGUEL

Confesso que um tio meu, já falecido, ensinou-me as leis de Moisés.

D. NUNO

E conversas sobre isso com o padre Bartolomeu Lourenço?

MIGUEL se assusta com a pergunta, demora a responder.

\section{MIGUEL}

Ficamos amigos porque somos brasileiros, viemos no mesmo navio... Mas o padre Bartolomeu Lourenço é cristão-velho.

D. NUNO

Como podes afirmar isso?

\section{MIGUEL}

Pois ele não é um padre?!

D. NUNO

Sabes muito bem que a lei da limpeza de sangue é uma quimera. 
MIGUEL não sabe o que dizer.

$$
\text { D. NUNO }
$$

(apontando o dedo na cara

de MIGUEL)

Nunca te esqueça: nada que acontece

neste tribunal é falado ou ouvido

fora dele.

MIGUEL assente com a cabeça.

MIGUEL

Sim senhor.

D. NUNO observa de longe quando BARTOLOMEU e o CONDE preparam o fogo e o colocam dentro do invento.

A pequena platéia assombrada com o vôo de balão, que é um pouco maior que o outro, de um canto a outro do pátio.

Ao lado da RAINHA, entusiasmado, D. JOÃO cumprimenta BARTOLOMEU .

D. JOÃO

Estás de parabéns, Bartolomeu!

BARTOLOMEU

Graças a vossa majestade, vossa confiança e vossos investimentos!

D. JOÃO

Ainda precisas fazer caber pessoas...

BARTOLOMEU

Sim, majestade. Estou a tratar disso. 
BARTOLOMEU (cont'd)

(baixo)

Escrevi o sermão que vós me recomendastes a homenagear a festa de Nossa Senhora.

ALEXANDRE se aproxima.

ALEXANDRE

Gostaria de me despedir. Vou a Coimbra, estudar cânones.

BARTOLOMEU repara na cara feia de D. NUNO e vai lhe falar.

\section{BARTOLOMEU}

Creio que quando alcançarmos o céu estaremos ainda mais próximos de Deus, Senhor.

D. NUNO

Devo adverti-lo: quem sois para ambicionares tal proximidade?

D. NUNO encara BARTOLOMEU alguns segundos.

D. NUNO

Lembre-se da torre de Babel.

D. NUNO silencia, BARTOLOMEU afasta-se dele.

As FREIRAS fazem doces com as mãos. BÁRBARA coloca a calda na palma da mão para que TRIGUEIRINHA experimente. Elas trocam olhares. PAULA e as outras fingem não ver. ANTONIA olha com ciúmes para TRIGUEIRINHA. 
D. NUNO, vestido de cardeal, D. JOÃO, a RAINHA, fidalgos e religiosos assistem ao sermão de BARTOLOMEU.

\section{BARTOLOMEU}

Dedico essas palavras singelas ao novo Cardeal da corte portuguesa, D. Nuno da Cunha Ataide, Bispo Capelão Mór, Inquisidor Geral, do Conselho de Estado d'Él-Rei e do seu Real Despacho...

D. NUNO olha, desconfiado, para Bartolomeu.

\section{BARTOLOMEU}

Pela primeira vez subo ao púlpito de uma capela régia. Lugar tão pouco temido e tanto a temer, onde me apresento com os olhos ainda fechados... Imenso deve a monarquia lusitana a Nossa Senhora, Virgem Mãe... Maria. Nome mais belo do que este não há.

BARTOLOMEU olha para a RAINHA, inclina a cabeça.

BARTOLOMEU

Foram três Marias a assistir, no calvário, a eleição do evangelista para filho de Nossa Senhora, ecce filius tuus, nascia assim São João para sua mãe adotiva...

D. NUNO comenta com religioso. 


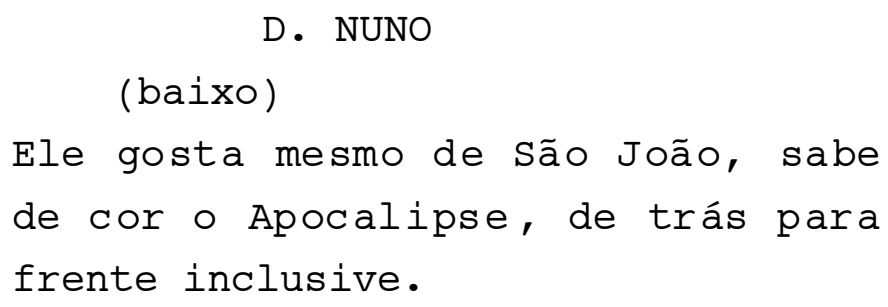

BARTOLOMEU percebe o comentário, ouve as duas últimas frases de D. NUNO antes de continuar.

\section{BARTOLOMEU}

D. João, nosso Rei...

(olha para D. JOÃO)

Tendes a mesma alcunha, sois o

mesmo protetor de todo o vosso

povo...

D. JOÃO olha satisfeito para BARTOLOMEU.

O ambiente escuro dá um ar soturno ao local de poucas mesas. Em uma delas, TOMAZ PINTO BRANDÃo lê seu poema alto, para dois BÊBADOS.

PINTO BRANDÃO

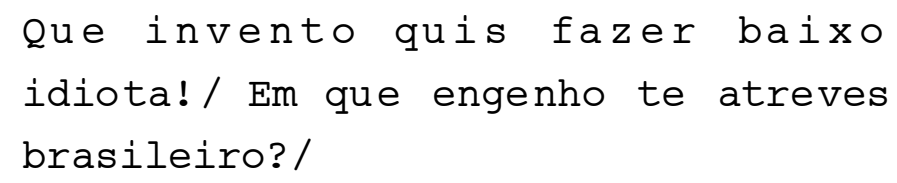

Em outra mesa, incomodados, JOÃO MENDES e ANTONIO JOSÉ.

$$
\text { PINTO BRANDÃO }
$$

Quis voar, ou asnear?/ Desejando águia ser sem ser gaivota?/ Melhor te fora na região remota/ sem pretenderes ser tu o primeiro/ que fazes esta célebre derrota... 
Os BÊBADOS se divertem. JOÃO MENDES e ANTONIO JOSÉ, levantamse e vão pagar a bebida.

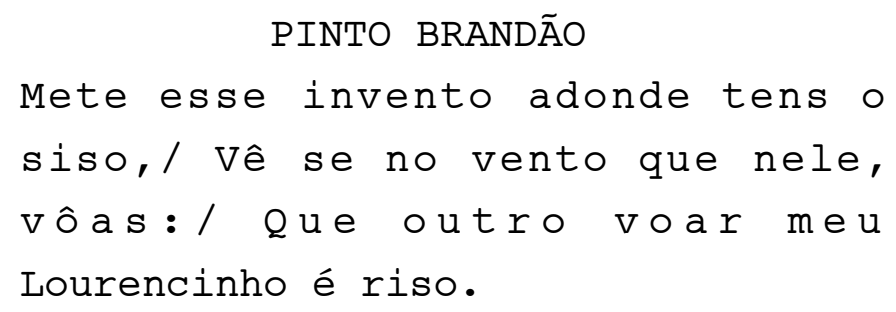

Os três riem ainda mais quando JOÃO MENDES e ANTONIO JOSÉ abandonam o local.

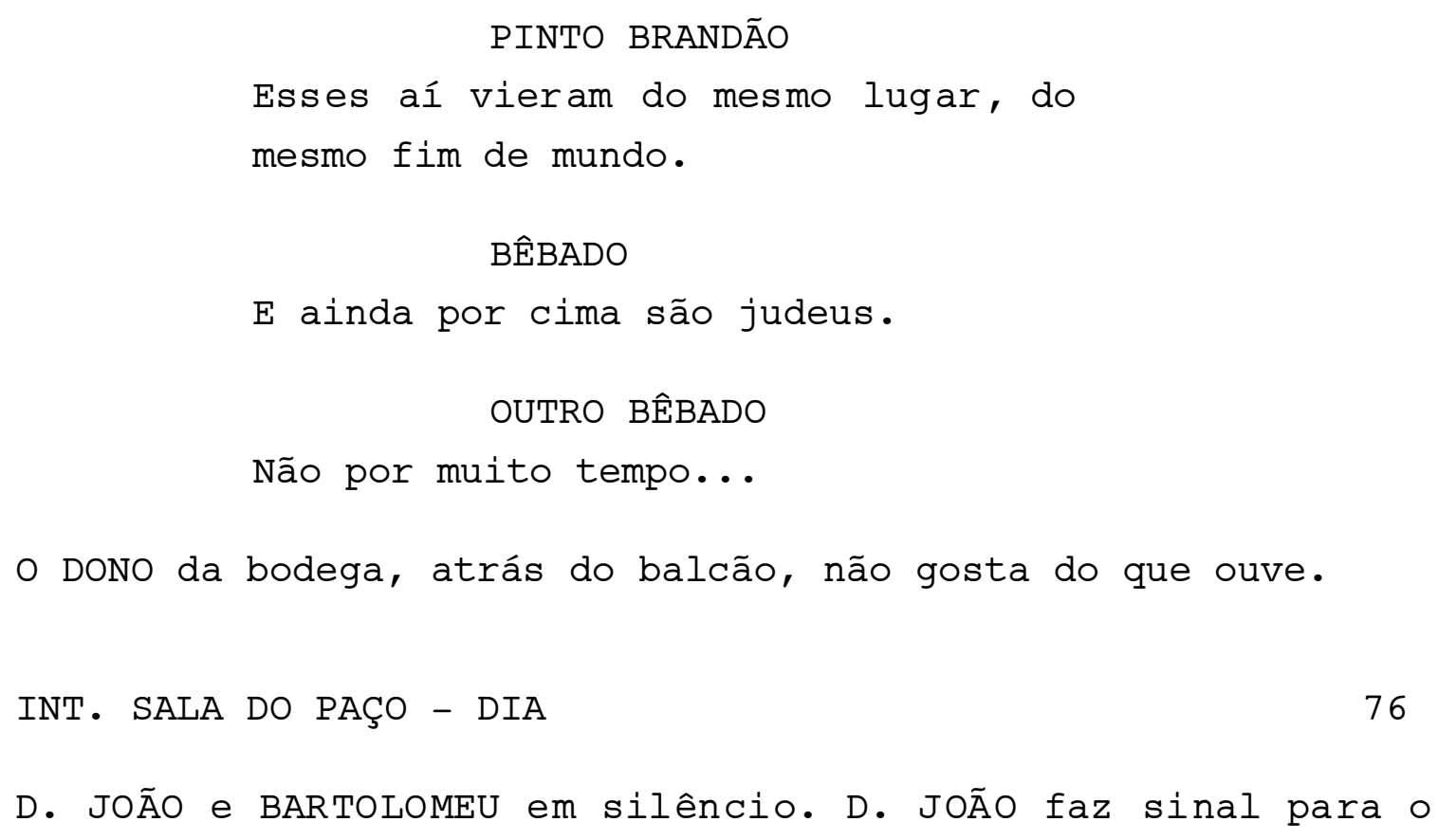

D. JOÃO e BARTOLOMEU em silêncio. D. JOÃO faz sinal para o serviçal sair. Eles ficam a sós.

BARTOLOMEU

Saibai que sinto-me mal perto de D. Nuno.

(pausa)

Estou a pensar que devo ir-me de Lisboa. 
D. JOÃO

D. Nuno não gosta mesmo de ti, Bartolomeu, nunca gostou. Creio que deves mesmo afastar-te um período de Lisboa.

\section{BARTOLOMEU}

Mas preciso seguir com a construção da maquina.

D. JOÃO

Tenho uma quinta afastada, a Quinta do Céu. Um local calmo para trabalhares sem ser incomodado.

D. JOÃO entrega um envelope a BARTOLOMEU.

\section{JOÃO}

E aqui uma correspondência estrangeira. códigos. Indecifráveis. Talvez não para vós, tente descobrir o que significam.

\section{BARTOLOMEU}

Claro Majestade. Saibas que fico deveras agradecido por vosso apoio e preocupação.

$$
\text { D. JOÃO }
$$

(rindo)

Não poderia haver melhor alcunha do que Quinta do Céu.

BARTOLOMEU sOrri. 


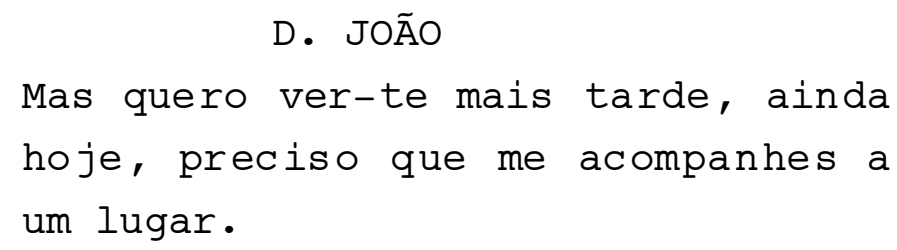

BARTOLOMEU faz que sim com a cabeça, intrigado.

77 EXT. CONVENTO - NOITE

A carruagem de D. JOÃo pára na porta do convento.

BÁRBARA acompanha D. JOÃO, que entra com BARTOLOMEU no quarto da TRIGUEIRINHA. BARBARA sai.

PAULA está ao lado de TRIGUEIRINHA na cama.

$$
\begin{gathered}
\text { D. JOÃO } \\
\text { (para TRIGUEIRINHA) } \\
\text { Cá estamos como prometido. }
\end{gathered}
$$

BARTOLOMEU fica parado perto da porta, sem jeito.

D. JOÃO vai ao encontro de TRIGUEIRINHA que o beija enquanto PAULA se aproxima de BARTOLOMEU sorrindo.

TRIGUEIRINHA empurra os dois para um quarto ao lado do seu e fecha a porta. Volta-se para D. JOÃo sorrindo.

TRIGUEIRINHA

o que, meu rei, trouxestes para mim hoje?

D. JOÃO abre um saquinho e puxa um colar de diamantes. TRIGUEIRINHA fica na frente de um espelho. D.JOÃo coloca o colar nela. 


$$
\begin{gathered}
\text { D. JOÃO } \\
\text { Diretamente das Minas Gerais... }
\end{gathered}
$$

D. Jõ̃o pega a colcha que está em cima da cama e a coloca sobre a cabeça de TRIGUEIRINHA.

$$
\begin{gathered}
\text { D. JOÃO } \\
\text { Pareces tanto com Nossa Senhora! }
\end{gathered}
$$

PAULA e BARTOLOMEU ficam parados durante alguns segundos, olhando-se nos olhos.

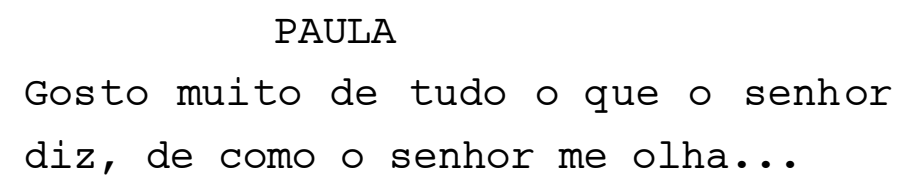

PAULA passa a mão na face de BARTOLOMEU, que parece constrangido.

\section{BARTOLOMEU \\ Desculpe-me, irmã. Mas não posso.}

PAULA fica de joelhos.

\section{PAULA}

Faço qualquer coisa por ti...

BARTOLOMEU coloca a mão sobre a cabeça de PAULA, fraternalmente e a ajuda a levantar-se.

80 EXT. PRAIA - NOITE

BRITES MARIA caminha à beira da água iluminada pela lua cheia, canta.

BARTOLOMEU parece esperar por ela, encostado em uma pedra. 


\section{BARTOLOMEU}

Sabia que a encontraria aqui.

BRITES MARIA

Padre Bartolomeu...

BARTOLOMEU

Bartolomeu de Gusmão.

Ele se curva, olhando penetrante, para os olhos dela. BARTOLOMEU

Ao teu dispor. Posso chamar-te apenas de Maria?

\section{BRITES MARIA}

Se preferes assim... mas o que queres de mim?

BARTOLOMEU

Preciso que me ajudes. Mas é um segredo. Não podes dizer a ninguém o que vou te pedir... Nem a tua mãe.

\section{BRITES MARIA}

Juro-o.

BARTOLOMEU aponta para um pequeno barco próximo.

$$
\text { BARTOLOMEU }
$$

Vês?... Vamos até lá?

BRITES MARIA faz que sim com a cabeça, eles vão até o barco. BARTOLOMEU entra e dá a mão para BRITES MARIA que entra também.

Eles se sentam no pequeno barco ancorado na beira da água. 
Um grande pássaro preto voa em círculos sobre eles e depois aterrisa perto do barco.

81 INT - SALA DO PAÇO - DIA

D. JOÃO e BARTOLOMEU estão sozinhos tomando chá. o envelope que D. JOÃO havia entregado a BARTOLOMEU nas mãos do REI.

\section{BARTOLOMEU}

Disse que não poderia, que não

tinha interesse. Jogou-se aos meus pés e chorou...

D. JOÃO

Lamentável. Insistiam muito, terminei por concordar.

BARTOLOMEU olha para o chão. D. JOÃo mostra o envelope.

$$
\text { D. JOÃO }
$$

Tinha certeza que serias capaz de decifrá-las!

(pausa)

Quanto a Alexandre, será o secretário do embaixador em Paris.

\section{BARTOLOMEU}

Vossa Real Pessoa tem sido muito boa para todos nós, Majestade...

BARTOLOMEU beija a mão do REI, que a retira rapidamente.

$$
\text { D . JOÃO }
$$

Deixe disso, Voador! 
TRIGUEIRINHA despacha MENSAGEIRO do rei, entra correndo, encontra PAULA na capela rezando, fala no seu ouvido.

PAULA nem termina a reza, faz o sinal da cruz e alcança TRIGUEIRINHA ainda no caminho da porta.

ANTONIA, ansiosa, olha as duas saindo.

No corredor, PAULA olha o céu que escurece pela janela. TRIGUEIRINHA afasta-se dela.

TRIGUEIRINHA encontra BÁRBARA na sala do oratório.

\section{TRIGUEIRINHA}

Parece que ele não virá mais.

\section{BÁRBARA}

Isso é o que veremos. Antonia irá nos ajudar.

ANTÔNIA e BÁRBARA, sentadas à frente de CATARINA SALEMA. Na mesa a balança com a mandrágora em um dos pratos e uma pedra clara e chata na outra.

\section{BÁRBARA}

Sei que é arriscado, mas pagarei bem à senhora.

\section{CATARINA}

Doidice. Absolutamente não farei isso!

BÁRBARA tira algumas moedas de ouro da bolsa e mostra a CATARINA. 


\section{CATARINA}

Por tão pouco, nem pensar.

BÁRBARA mostra o colar de diamantes que TRIGUEIRINHA ganhou do REI.

\section{BÁRBARA}

E isto?

CATARINA arranca-o das mãos dela e o olha contra a luz. CATARINA

Bom, posso tentar.

(Para si mesma)

Mandragora...

(para elas)

Mas se não conseguir, não o devolverei, nam as moedas.

CATARINA tira a pedra e coloca o colar e as moedas no outro prato da balança, o prato com a mandrágora se desequilibra com o peso.

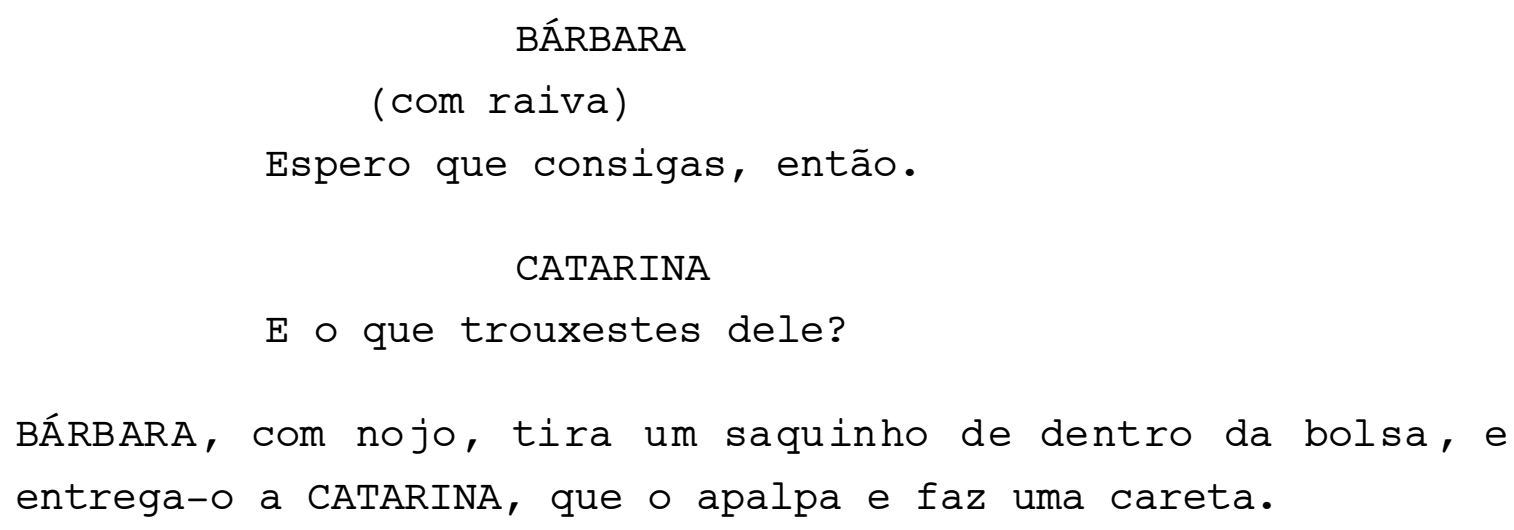

84 EXT. RIBEIRA/PRAIA - AMANHECER

BRITES MARIA está amarrada às madeiras preparadas para a fogueira. BARTOLOMEU corre em sua direção, desamarra a corda e a leva desfalecida no ombro com uma das mãos. 
BARTOLOMEU anda rápido, tenta voar batendo com o outro braço mas não consegue. Repara no grande pássaro preto andando à sua frente, segue-o até o mar.

BARTOLOMEU entra no mar com BRITES MARIA, mergulha sua cabeça na água, ela acorda e o abraça forte.

O sol se levanta, enorme bola vermelha, no horizonte.

BARTOLOMEU está mais velho. Puxa uma mula carregada com provisões e maletas. Ao seu lado vai SANTA MARIA, rapazote.

\section{BARTOLOMEU}

Chegaste em boa hora. Sentia-me só sem Alexandre.

SANTA MARIA

A mãe que está muito velha, acha que nunca mais irá ver-nos.

\section{BARTOLOMEU}

Ela tem razão...

SANTA MARIA percebe que BARTOLOMEU também tem razão. Andam calados um trecho.

\section{SANTA MARIA}

Joana vai bem, vive em uma ilha chamada Nosia Senhora do Desterro, fica no sul.

\section{BARTOLOMEU}

Tenho um sermão em homenagem a Nossa Senhora do Desterro. (pausa)

E o pai? 
SANTA MARIA

Feliz com a tua ligação com el Rei.

BARTOLOMEU

D. João só nos ajuda porque quer abarcar o mundo.

SANTA MARIA

$\mathrm{E}$ tu cres que vais conseguir mesmo?

BARTOLOMEU

(rindo)

Claro que não!

(sério)

o mundo é de todos. E o céu também.

BARTOLOMEU olha para o céu e SANTA MARIA sorri curioso.

BARTOLOMEU lava as mãos, o rosto, bebe água.

SANTA MARIA acaba de arrumar suas coisas em um canto.

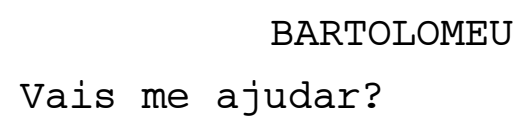


BARTOLOMEU observa as estrelas com um telescópio menos rudimentar, faz anotações em seu novo mapa celeste. SANTA MARIA, ao seu lado, orgulha-se do irmão. BARTOLOMEU guarda seu mapa.

\section{BARTOLOMEU}

Acreditas que Jesus Cristo, Nossa Senhora e o Espírito Santo estão aí?

$$
\text { (apontando o céu) }
$$

Sobre nós?

\section{SANTA MARIA}

Tu não?

BARTOLOMEU

Creio no quinto império.

SANTA MARIA se assusta, fica pensativo.

\section{BARTOLOMEU}

A redenção foi prometida aos judeus nas sagradas escrituras.

SANTA MARIA

Mas o santo ofício...

\section{BARTOLOMEU}

Há um único Deus, meu irmão. E ele não é semelhante ao homem.

Os dois se calam.

BARTOLOMEU volta a olhar para o céu.

SANTA MARIA observa o irmão, depois o céu. 
D. NUNO ouve ANTÔNIA em seu gabinete.

\section{ANTÔNIA}

Fui junto porque não pude acreditar que tivesse coragem... Sei que é minha própria irmã, mas não posso deixar de contar ao senhor.

$$
\text { D. NUNO }
$$

Fizeste muito bem, Dona Antônia.

D. NUNO observa-a por alguns segundos.

D. NUNO

E o padre Bartolomeu Lourenço de Gusmão, o que tem a ver com isso?

ANTÔNIA chora.

$$
\text { D. NUNO }
$$

Coragem, irmã.

\section{ANTÔNIA}

o padre Bartolomeu esteve no convento com el Rei. Paula queria que ele voltasse mais vezes.

D. NUNO se levanta e a acompanha até a porta.

$$
\text { D. NUNO }
$$

Teremos de prendê-las, mas garanto que não lhes faremos nenhum mal. 
CATARINA SALEMA e D. NUNO estão frente a frente. BRITES MARIA, acuada, em um canto. Na porta dois inquisidores.

D. NUNO

E então, onde está o colar?

BRITES MARIA

Mas que colar?!

$$
\text { D.NUNO }
$$

Ou a senhora me entrega o colar ou aquela...

(apontando para Brites

Maria)

... senhorita vai junto.

CATARINA, raivosa, pega o colar de diamantes embaixo da cama e o entrega a D. Nuno, que o olha com atenção e o guarda no bolso.

D. NUNO

Nunca mais irá meter-te nisso.

D. NUNO sai, inquisidores levam CATARINA. BRITES MARIA olha para a mãe desolada.

\section{BRITES MARIA}

$$
\text { ( gritando) }
$$

\section{Mãe!}

BRITES MARIA senta na mesa chorando, coloca a mão na balança vazia, que se desequilibra. 
BARTOLOMEU coloca a mão na cabeça de D. JOÃO, desfalecido na cama. Ao lado, sentada e preocupada, está a RAINHA.

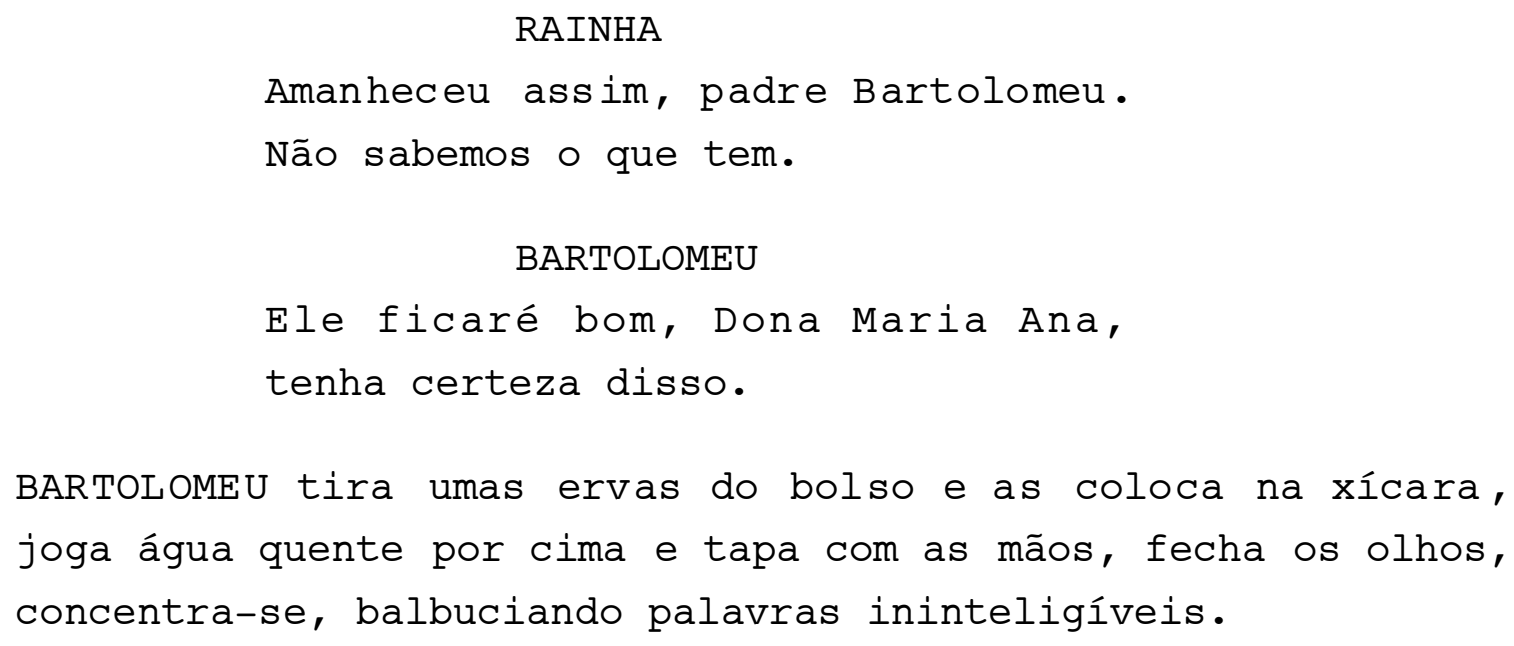

\section{BARTOLOMEU}

Ajude-me a fazê-lo beber isso.

BARTOLOMEU, uma mão sobre a testa do rei, dá a bebida para ele enquanto a RAINHA segura sua cabeça.

91 EXT/INT - QUINTA DO CÉU - DIA

BARTOLOMEU e BRITES MARIA trazem um burro carregado de palha fina.

SANTA MARIA vem ajudar.

\section{BARTOLOMEU}

Maria, meu irmão caçula, João

Alvares de Santa... Maria!

BRITES MARIA

Ainda vais ser de Gusmão também.

SANTA MARIA sorri. 


\section{SANTA MARIA \\ Bem pode ser... \\ ( para BARTOLOMEU) \\ Vou caminhar um pouco.}

BARTOLOMEU faz que sim com a cabeça. SANTA MARIA sai.

BRITES MARIA arruma seu canto e começa a tecer a palha enquanto BARTOLOMEU escreve em seu caderno.

De vez em quando eles se olham, em silêncio.

92 EXT/INT - CONVENTO - DIA

MATEUS e os INQUISIDORES entregam uma "ordem de busca' para as MADRES SUPERIORAS e entram no convento.

As MADRES rezam com BÁRBARA.

TRIGUEIRINHA e PAULA, mais afastadas, dão-se as mãos. ANTÔNIA olha de longe.

As MADRES abrem a porta e as FREIRAS são levadas pelos INQUISIDORES.

TRIGUEIRINHA acompanha PAULA. Logo atrás vem BÁRBARA de cabeça baixa.

93 INT - TRIBUNAL - NOITE

D. NUNO, glorioso, observa escondido pelo buraco da parede da masmorra as três FREIRAS sentadas no chão.

PAULA chora em silêncio, ao seu lado TRIGUEIRINHA esbraveja.

TRIGUEIRINHA

(para BÁRBARA)

Tudo culpa tua!

(MORE) 
TRIGUEIRINHA (cont'd)

Confiar naquela velha Catarina

Salema. Como pudeste acreditar que ela o traria de volta?!

\section{BARBARA}

Por que Antonia não foi presa?

Pensaste nisso?

TRIGUEIRINHA olha sério para ela.

94 INT - SALA DO PAÇO - NOITE

D. JOÃo esforça-se para ficar sentado, está ainda febril. BARTOLOMEU, sentado ao seu lado, olha-o preocupado.

D. JÕ̃O

As duas estão presas, inclusive

Madre Paula. Parece que o

delataram...

D. JOÃo coloca algumas moedas de ouro dentro de um saquinho e o oferece ao BARTOLOMEU.

D. JOÃO

D. Nuno quer prender-te, é melhor que fiques na Quinta por um bom período. Sem vir aqui.

BARTOLOMEU pega o saquinho com as moedas e segura a mão de D. Jõ̃o com força.

\section{BARTOLOMEU}

Sim senhor... Vossa Majestade precisa recuperar-se logo.

D. JÕ̃O

Não te preocupes, já estou bom. 
Os carvoeiros, armados como "soldados da fé" carregam as achas de lenha à frente da lenta procissão de dominicanos com o pendão da Inquisição.

Atrás deles, os penitentes de sambenito entre dois guardas, por ordem de gravidade das culpas, todos descalços. MIGUEL e MARIA entre os condenados a ler penitência, com cabeças nuas, seguram a vela acesa; os condenados às fustigações, às galeras e prisões, com cabeça coberta pela carocha, a vela acesa na mão; os relaxados condenados à morte: CATARINA SALEMA, dois amordaçados e um outro com livro pendurado no pescoço, são acompanhados por dois "familiares" e dois religiosos jesuítas, suas velas apagadas.

Nos sambenitos de cada um, os destinos estampados: o próprio retrato metido em chamas, para os negativos e diminutos; fogo revolto, para os que mereciam a morte mas por terem confessado foram perdoados; apenas uma cruz sobre o hábito, para os reconciliados, com culpas leves.

A procissão segue com os "vagabundos" que carregam as efígies de papelão dos que seriam queimados mas fugiram e as efígies com o caixão cheio de ossos ao lado, dos que morreram na prisão.

Em seguida uma tropa de "familiares" a cavalo, seguida dos altos dignatários da Inquisição, cercados de portadores com tochas acesas.

Atrás deles, a nobreza muito bem vestida, com a insígnia da Inquisição sobre o peito.

D. NUNO vem montado em um cavalo branco, coberto por um chapéu preto de fita roxa, traje violeta, escoltado por MATEUS e pela sua guarda particular. 
Durante toda a lenta procissão, a multidão, absorta, compacta e curiosa, contempla as autoridades, observada por soldados armados. Muitos caçoam dos condenados, gritam, comentam entre si. Vendedores de refresco circulam entre eles.

96 EXT - ROSSIO - DIA

No anfiteatro sentam-se aos poucos no alto CATARINA SALEMA e os relaxados, acompanhados dos jesuítas. Abaixo, MIGUEL, MARIA COUTINHO e os outros sentenciados.

Ao lado, em um grande altar ricamente ornado, sentam-se conforme hierarquia, D. NUNO, os inquisidores, funcionários do Santo ofício, eclesiásticos, frades e personalidades convidadas. Na frente há uma cadeira muito alta.

Em um balcão à frente da praça, D. JOÃO, a RAINHA, D. FRANCISCO e membros da corte, todos muito bem vestidos.

Em outro balcão, O MARQUES, O CONDE, fidalgos, nobres e convidados, alguns estrangeiros.

BARTOLOMEU, assustado, vê tudo de longe, escondendo-se.

A multidão se aproxima e se aperta.

Todos olham o pregador dominicano sentar-se na cadeira alta à frente.

\section{PREGADOR}

Lisboa assiste a mais um auto-defé. A Santa Inquisição a defender a fé católica, a conservar o aumento dela. 
PREGADOR (cont'd)

A perseguir os hereges e apóstatas contrários a ela, a prender e castigar conforme os direitos e sagrados cânones a todos os pertubadores de nossa santa religião cristã.

A multidão espremida tenta se aproximar ainda mais, porém é impedida pelos soldados. TOMÁz PINTO BRANDÃO repara em BRITES MARIA em um canto, olhando CATARINA. Seus amigos se divertem, ele não, está chocado e tenta chegar perto de BRITES, que percebe e se esconde na multidão.

\section{PREGADOR}

Como estão a esperar pelo Messias, quando o Messias já cá esteve na Terra, para ensinar aos homens de boa vontade a verdade divina... o Messias foi crucificado por judeus...

(apontando o anfiteatro)

O sangue infecto dessa gente da nação contamina Portugal, é preciso pois reforçar o poder do santo ofício porque o castigo divino cairá sobre o reino caso as heresias, as blasfêmias, os sacrilégios persistam...

Fidalgo traz uma lenha para D. JOÃO, que a segura e a devolve.

\section{FIDALGO}

Será a primeira a queimar, majestade. 
BARTOLOMEU, horrorizado, vê CATARINA entre os condenados, MIGUEL e MARIA no meio dos penitentes. MIGUEL vê BARTOLOMEU e abaixa os olhos.

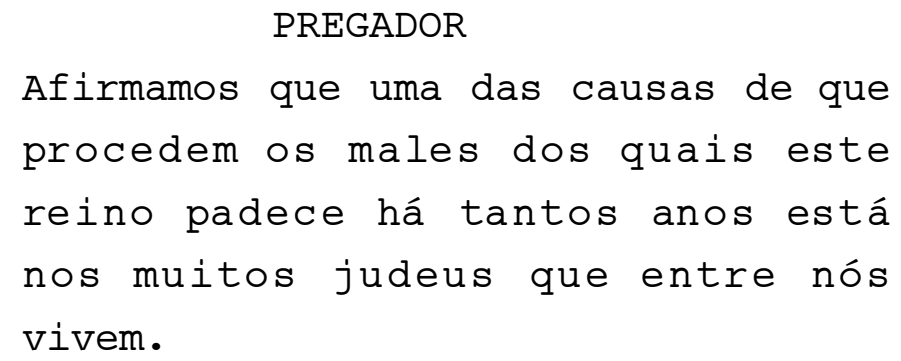

\section{MULTIDÃO}

Amém .

O dominicano desce da cadeira e sobe um inquisidor para ler as sentenças.

\section{INQUISIDOR}

Miguel de Castro Lara. Cristãonovo, natural do Rio de Janeiro, Brasil. Filho de João Tomás Brum e Branca Gomes Coutinho. Advogado. Acusado de judaísmo.

MIGUEL levanta, vai até o altar e se ajoelha de frente para a cadeira alta.

\section{INQUISIDOR}

o réu tendo-se encontrado com pessoa de sua nação, ambos se confessaram por adeptos da lei de Moisés, fora da qual não há salvação .

(MORE) 
INQUISIDOR (cont'd)

o réu pois, confessou obedecer os

ritos e cerimônias judáicas, a

jejuar e rezar, não comer carne de

porco, lebre, coelho, banha e peixe

sem escama, não trabalhar aos

sábados. O réu se arrepende e voltará a seguir somente a santa Igreja católica?

MIGUEL

Arrependo-me muito de minhas culpas e prometo em nome de Deus e do Senhor Jesus Cristo a seguir somente a Santa Igreja Católica e nada mais até o dia de minha morte.

INQUISIDOR

o Santo ofício crê em vosso testemunho e o perdoa. Vossa sentença será o cárcere e o hábito penitencial a arbítrio dos inquisidores, com confisco de bens.

MIGUEL volta a sentar-se no anfiteatro.

\section{INQUISIDOR}

Dona Maria Coutinho. Cristã-nova, natural do Rio de Janeiro, Brasil. Filha de Baltazar Rodrigues Coutinho e Brites Cardosa. Casada com Miguel de Castro Lara. Acusada de judaísmo.

MARIA levanta e vai até a frente da cadeira alta, ajoelha-se. BARTOLOMEU, entristecido, vê a reação de MIGUEL. 
D. NUNO vê BARTOLOMEU escondido. BARTOLOMEU olha para D. NUNO que fala no ouvido de MATEUS, apontando com a cabeça onde ele está. BARTOLOMEU se afasta e D. NUNO o segue com o olhar.

MATEUS acaba de falar com INQUISIDOR que desce do palco e vai em direção de onde BARTOLOMEU estava.

97 EXT - RUAS - ENTARDECER

BARTOLOMEU corre pelas ruas desertas, passa em frente à casa de MIGUEL, lacrada pela inquisição.

98 EXT. RIBEIRA - NOITE

BARTOLOMEU passa pelas madeiras prontas para as fogueiras próximas a muita sujeira, lixo, bichos mortos.

BARTOLOMEU ouve a lamentação que se aproxima e afasta-se rapidamente.

De longe, BARTOLOMEU assiste aterrorizado a procissão chegar, cruz da misericórdia à frente, os condenados a morte atrás: CATARINA SALEMA, dois amordaçados e outro com livro pendurado ao pescoço, todos vestidos de branco com as velas apagadas nas mãos.

Eles são metidos nas barracas de madeira, sentam-se nos bancos.

Religiosos rondam os condenados, instando-os a arrepender-se antes de queimar.

\author{
JESUÍTA \\ Reconcilie-se com a Igreja!
}




\begin{abstract}
OUTRO JESUÍTA
Ficas entregue ao demônio que está junto a ti para lhe receber a alma e a levar às chamas do inferno!
\end{abstract}

Os "familiares" com tochas nas mãos colocam fogo nas madeiras, que começam a pegar fogo. As chamas não chegam à cintura dos relaxados, que queimam devagar.

o povo grita excitado. Muitos riem, comemoram. BARTOLOMEU afasta-se, caminha cada vez mais rapidamente.

Do alto, BARTOLOMEU vê os familiares em fila, com as tochas nas mãos, no final da fila as fogueiras, parece uma grande cobra de fogo.

BARTOLOMEU desesperado, cai de joelhos no chão. Olha para o céu.

\title{
BARTOLOMEU
}

(grita)

Não posso crer no que vejo. A brutalidade dos homens. A covardia dos poderosos. A injustiça para com os nossos irmãos. O povo de Deus?! o que será desta terra?

BRITES MARIA se aproxima dele, os olhos cheios de lágrimas. BRITES MARIA

o que os homens fazem uns com os outros e o que fizerem à terra, recairá sobre eles mesmos.

BARTOLOMEU e BRITES MARIA se encaram entristecidos e em silêncio. 
BARTOLOMEU

Sinto muito por vossa mãe.

Eles olham para o céu que se encobre de nuvens carregadas. Estrondo de trovões, raios.

Sob o céu carregado e o vento forte, BARTOLOMEU e BRITES MARIA, já quase sem fôlego, entram com pressa.

SANTA MARIA corre até eles.

\section{SANTA MARIA}

o que aconteceu?

\section{BARTOLOMEU}

Ajude-nos!

SANTA MARIA ajuda BARTOLOMEU a puxar para fora da quinta as velas brancas escondidas debaixo de panos.

BRITES MARIA arrasta a naveta de palha grossa, com um leme em uma das pontas. SANTA MARIA vem ajudá-la, depois encaixa as cordas nas velas.

BARTOLOMEU folheia e queima seu caderno, outros papéis e alguns livros. SANTA MARIA se aproxima dele.

\section{SANTA MARIA}

Que estás a fazer?

\section{BARTOLOMEU}

Minha máquina não servirá nem a este nem a nenhum outro reino.

BARTOLOMEU tira a batina e segura SANTA MARIA com firmeza. 


\section{BARTOLOMEU}

$$
\begin{aligned}
& \text { Prometa-me que ninguém saberá } \\
& \text { jamais como ela funciona. }
\end{aligned}
$$

$$
\text { SANTA MARIA }
$$

Prometo, sim.

\section{BARTOLOMEU}

Jure!

\section{SANTA MARIA}

Juro por Deus, pelo único Deus!

BARTOLOMEU, nervoso, joga vários fluidos dentro de um caldeirão, coloca fogo e prende-o sob as velas, que começam a inflar.

o balão lembra uma caravela.

BARTOLOMEU abraça SANTA MARIA e entra na naveta de palha.

\section{BARTOLOMEU}

Serei Miguel Santos agora. Se

precisares, podes me delatar. Vou

para bem longe de Portugal.

\section{SANTA MARIA \\ Quero ir-me contigo.}

BARTOLOMEU olha para BRITES MARIA, estende a mão para que ela vá com ele.

BRITES MARIA fica indecisa. O balão começa a subir, devagar, enquanto os dois se despedem com os olhos, em silêncio.

SANTA MARIA e BRITES MARIA vêem o balão subindo e se afastando. 
BARTOLOMEU acena para SANTA MARIA e para BRITES MARIA, vê o pássaro preto rondando a Quinta. Cada vez mais longe, os prados e campos. E depois de tudo, o furacão.

101 EXT - RUAS DE LISBOA - DIA

o furacão se aproxima, um vento fortíssimo arrasta tudo o que encontra pela frente.

$102 \quad \mathrm{EXT}-\mathrm{CEEU}-\mathrm{DIA}$

BARTOLOMEU voa sobre o mar pelo céu azul até sumir no horizonte. 


\section{Filmografia Inspiradora}

Brava Gente Brasileira

Direção de Lúcia Murat

Rio de Janeiro, 2000.

Carlota Joaquina: Princesa do Brasil

Direção de Carla Camurati

Rio de Janeiro, 1995.

Desmundo

Direção de Alain Fresnot

São Paulo, 2003.

Giordano Bruno

Direção de Giuliano Montaldo

Itália, França, 1973.

Hans Staden

Direção de Luís Alberto Pereira

São Paulo, 1999.

1492 A Conquista do Paraíso

Direção de Ridley Scott

Inglaterra, Espanha, França, 1992.

O Descobrimento do Brasil

Direção de Humberto Mauro

Rio de Janeiro, Bahia, 1937.

O Judeu

Direção de Jom Tob Azulay

Brasil, Portugal, 1991.

O Martírio de Joana D'Arc

Direção de Carl Th. Dreyer

França, 1928.

Os Inconfidentes

Direção de Joaquim Pedro de Andrade.

Rio de Janeiro, 1972.

O Sétimo Selo

Direção de Ingmar Bergman

Suécia, 1956. 


\section{Referências Bibliográficas}

ALBUQUERQUE, Manoel Maurício de. Pequena História da Formação Social Brasileira. Rio de Janeiro, Graal, 1981.

ARISTOTELES. Poética. São Paulo, Ed. Ars Poética, 1982.

ASSIS, José Eugenio de Paula. Bartolomeu Lourenço de Gusmão. São Paulo, Editora Saraiva, 1967.

AZEVEDO, J. Lucio de. História dos Cristãos-Novos Portugueses. Lisboa, Clássica Editora, 1989.

BETHENCOURT. Francisco. História das Inquisições. São Paulo, Companhia das Letras, 2000 .

BLACKER, Irwin. R. The Elements of Screenwriting. New York, Longman, 1996.

BLOCH, Ernst. O Princípio Esperança. Rio de Janeiro, EdUERJ: Contraponto, 2005.

BOSI, Alfredo. Dialética da Colonização. São Paulo, Companhia das Letras, 2002.

CAMÕES, Luís de. Lírica. São Paulo, Editora Cultrix, 1995.

CARNEIRO, Maria Luiza Tucci. Preconceito Racial em Portugal e Brasil Colônia. São Paulo, Editora Perspectiva, 2005.

CARRIÈRE, Jean-Claude. A Linguagem Secreta do Cinema. 3. imp. Rio de Janeiro, Editora Nova Fronteira, 1995.

CORTESÃO, Jaime. Alexandre de Gusmão e o Tratado de Madrid. Rio de Janeiro, Instituto Rio Branco, s/d.

DINES, Alberto. Vínculos do Fogo - Antônio José da Silva, o Judeu, e outras Histórias da Inquisição em Portugal e no Brasil. São Paulo, Companhia das Letras, 1992.

e ELEUTÉRIO, Victor (Org.). O Judeu em Cena. São Paulo, EDUSP, 2005.

DUMONT, Santos. O que eu vi. O que nós veremos. São Paulo, Hedra, 2000.

ELIADE, Mircea. Ferreiros e Alquimistas. Lisboa, Coleção Antropos, s/d.

EGRI, Lajos. The Art of Dramatic Writing. New York, Ed. Simon and Schuster, 1960. 
EYMERICH, Nicolau. Manual dos Inquisidores. Rio de Janeiro, Editora Rosa dos Tempos, 1993.

FAUSTO, Boris. História do Brasil. São Paulo, EDUSP, 1994.

FELLINI, Federico. Fazer um filme. Rio de Janeiro, Civilização Brasileira, 2000.

FLANDRIN, Jean-Louis e MONTANARI, Massimo. História da Alimentação. São Paulo, Estação Liberdade, s/d.

GINZBURG, Carlo. O Queijo e os Vermes. São Paulo, Companhia das Letras, 2001.

GOMES, Paulo Emilio Salles Gomes. "A Personagem Cinematográfica". IN - A Personagem de Ficção. 9. ed. São Paulo, Editora Perspectiva, 1995.

Cinema: Trajetória no Subdesenvolvimento. São Paulo, Ed. Terra e Paz, 1996.

GORENSTEIN, Lina. A Inquisição Contra as Mulheres. Rio de Janeiro, séculos XVII e XVIII. São Paulo, Humanitas, 2005.

GORENSTEIN, Lina e CARNEIRO, Maria Luiza Tucci. (Org.) Ensaios sobre a Intolerância. Inquisição, marranismo e anti-semitismo. 2.ed. São Paulo, HUMANITAS, 2005.

HAUSER, Arnold. História Social da Arte e Literatura. São Paulo, Martins Fontes, 1995.

HERCULANO, Alexandre. História da Origem e Estabelecimento da Inquisição em Portugal. Porto Alegre, Editora Pradense, 2002.

HOLANDA, Sérgio Buarque de. (Dir.) História Geral da Civilização Brasileira. Tomo I: A Época Colonial. Rio de Janeiro, Bertrand Brasil, 2003.

Raízes do Brasil. Rio de Janeiro, Livraria José Olympio Editora, 1956.

HOBSBAWM, E. J. Revolucionários. São Paulo, Editora Paz e Terra, 2003.

KRAMER, Heinrich e SPRENGER, James. O Martelo das Feiticeiras. Rio de Janeiro, Editora Rosa dos Tempos, 1991.

LAWSON, John Howard. Teoria y Técnica del Guion cinematográfico. La Habana, Ediciones ICAIC, 1963.

LEE, Lance. A Poetics for Screenwriters. Austin, University of Texas Press, 2001.

LOURENÇO, Eduardo. Mitologia da Saudade. São Paulo, Companhia das Letras, 1999. 
O Labirinto da Saudade - Psicanálise Mítica do Destino Português. 2. ed. Lisboa, Publicações Dom Quixote, 1982.

MÁRQUEZ, Gabriel García. Como Contar um Conto. 4. reimp. Rio de Janeiro, Casa Jorge Editorial,

MARTINS, Oliveira. História de Portugal. Lisboa, Guimarães Editores, 2004.

MATTOSO, José. (org.) História de Portugal. V. 4. Portugal, Editorial Estampa, s/d.

MCKEE, Robert. Story. New York, ReganBooks, 1997.

NAZARIO, Luiz. AUTOS-DE-FÉ Como espetáculos de massa. São Paulo, Humanitas, 2005.

NOGUEIRA, Carlos Roberto Figueiredo. Bruxaria e História. São Paulo, Editora Ática, 1991.

NOVINSKY, Anita. Inquisição: prisioneiros do Brasil. Rio de Janeiro, Editora Expressão e Cultura, 2002.

ORICCHIO, Luiz Zanin. Cinema de novo: um balanço crítico da Retomada. São Paulo, Estação Liberdade, 2003.

PALLOTTINI, Renata. Dramaturgia A construção do personagem. São Paulo, Editora Ática, 1989.

PERES, Damião e CERDEIRA, Eleutério. (Org.) História de Portugal. V. 6. Barcelos, Portucalense Editora, s/d.

QUEVEDO, Franz Baiz. La Ventana Impossible. Caracas, Fundarte, 1993.

SANTOS, Boaventura de Sousa. Pela Mão de Alice - O social e o político na pósmodernidade. 7. ed. São Paulo, Cortez Editora, 2000.

SARAIVA, Antonio José. Inquisição e Cristãos-Novos. Lisboa, Editorial Estampa, 1985.

SARAIVA, José Hermano. História Concisa de Portugal. Mira-Sintra, Publicações Europa-América, 1987.

SARAMAGO, José. Memorial do Convento. São Paulo, DIFEL, 1982.

SERRÃO, Joaquim Veríssimo. História de Portugal. 2. ed. Lisboa, Editorial Verbo, s/d.

SERRÃO, Joel. Dicionário da História de Portugal. V.3. Porto, Livraria Figueirinhas, 1992. 
STANISLAVSKY, Constantin. A preparação do Ator. 5. ed. Rio de Janeiro, Civilização Brasileira, 1982.

\section{6.}

A Construção da Personagem. 2. ed. Rio de Janeiro, Civilização Brasileira,

TAUNAY, Afonso de E. Bartolomeu de Gusmão - Inventor do Aeróstato. São Paulo, Editora Leia, 1942.

TIERNO, Michael. Aristotle’s Poetics for Screenwriters. New York, Hyperion, 2002.

XAVIER, Ismail. O Discurso Cinematográfico: a Opacidade e a Transparência. Rio de Janeiro, Editora paz e terra, 1977.

Sétima Arte: Um Culto Moderno. São Paulo, Editora Perspectiva, 1978.

------. D. W. Griffith: O Nascimento de um Cinema. São Paulo, Editora

Brasiliense, 1984.

Alegorias do Subdesenvolvimento: Cinema Novo, Tropicalismo, Cinema Marginal. São Paulo, Editora Brasiliense, 1993.

O cinema no Século (org.). Rio de Janeiro, Imago, 1996.

O Cinema Brasileiro Moderno. Rio de Janeiro, Editora Paz e Terra, 2001. 